Journal of the Society for the Study of Architecture in Canada Le Journal de la Société pour l'étude de l'architecture au Canada

\title{
The Second St. George's Anglican Church, Kingston, Upper Canada, 1822-1828
}

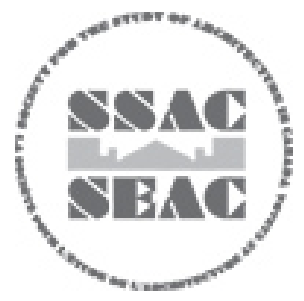

\section{Paul Christianson}

Volume 45, numéro 1, 2020

URI : https://id.erudit.org/iderudit/1075075ar

DOI : https://doi.org/10.7202/1075075ar

Aller au sommaire du numéro

Éditeur(s)

SSAC-SEAC

ISSN

2563-8696 (numérique)

Découvrir la revue

Citer cet article

Christianson, P. (2020). The Second St. George's Anglican Church, Kingston, Upper Canada, 1822-1828. Journal of the Society for the Study of Architecture in Canada / Le Journal de la Société pour l'étude de l'architecture au Canada, 45(1), 42-62. https://doi.org/10.7202/1075075ar d'utilisation que vous pouvez consulter en ligne. 


\section{THE SECOND ST. GEORGE'S ANGLICAN CHURCH, KINGSTON, UPPER CANADA, 1822-1828}

PAUL CHRISTIANSON is an emeritus professor of history at Queen's University who, after many years as a historian of seventeenth-century Britain, has become a historian of nineteenthcentury church architecture in Canada. After publishing several articles on Gothic Revival churches in the Kingston area and the impact of British Ecclesiologists on the architecture of Anglicans in Ontario, he has started to write the architectural history of a well-known classical church, St. George's Anglican in Kingston.
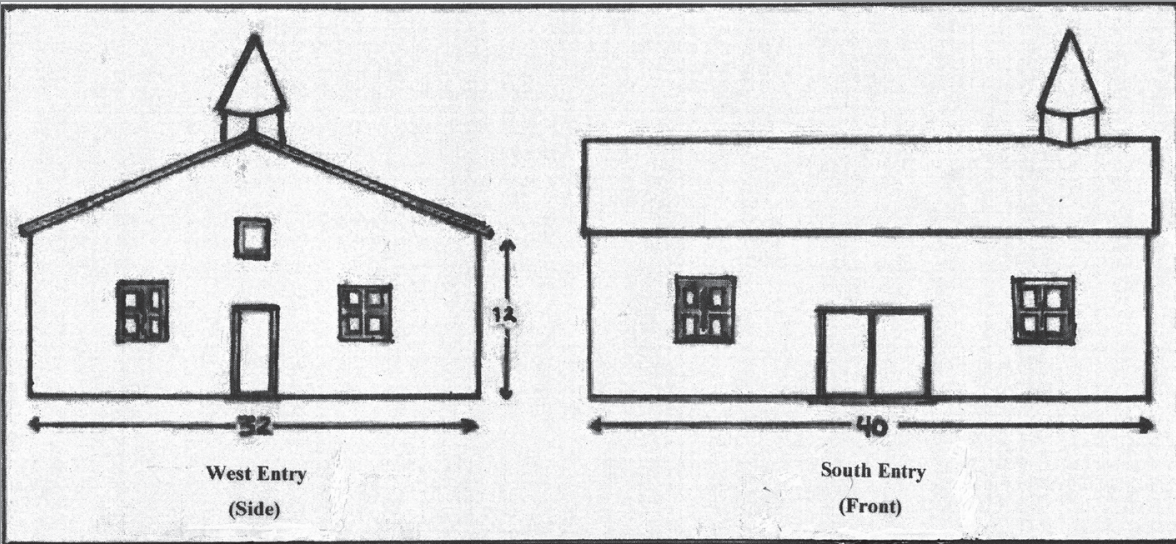

FIG. 1. ST. GEORGE'S ANGLICAN CHURCH, C. 1794. MEASUREMENTS IN FEET. | VARTY, "BUILDING IDENTITIES: ST. GEORGE'S ANGLICAN CHURCHES," P. 120, FIG. 5.
$>$ PAUL ChRISTIANSON ${ }^{1}$

n 1791, a gathering of relatively recent settlers, many of them Loyalists from the former British Colonies south of British North America, decided to build a church for those who wished to worship according to the rites of the Church of England and Ireland. As Carmen Nielson Varty has pointed out: "The benefactors of the first St. George's Church were an eclectic group of individuals who were most preoccupied with setting themselves upon the land, establishing familiar institutions, and recreating a viable North American community." 2 The church that they built represented their situation, life in a newly established small community with little wealth and fewer pretensions that drew upon the traditions of the North Americans that made up the majority of its members to build a modest, classically inspired building like most Anglicans in British North America in the late eighteenth and early nineteenth centuries (fig. 1). It was "a weatherboard church, 40 feet by 32 feet and 12 feet high, with a gabled roof and square windows." ${ }^{3}$ With larger numbers attending services, the church was expanded by twenty feet on the longer side and reorganized on the interior in 1803, with the pulpit "moved to the centre of the north side after the addition was complete." ${ }^{4}$ In recalling how it looked in 1813, Bishop Jacob Mountain offered a less than complimentary description: "The church is a long, low, blue, wooden building, with square windows, and a little cupola or steeple, for the bell, like the thing on a brewery placed at the wrong end of the building." ${ }^{5}$ Even with its new addition and galleries, the first St. George's represented a modest 


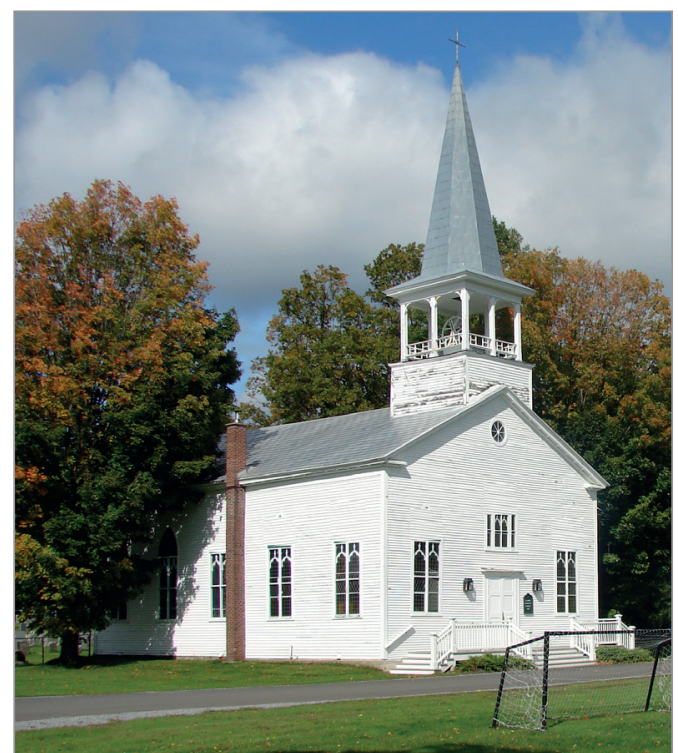

FIG. 2. ST. JAMES' ANGLICAN CHURCH, HATLEY, QC. | PAUL CHRISTIANSON, SEPTEMBER 2019.

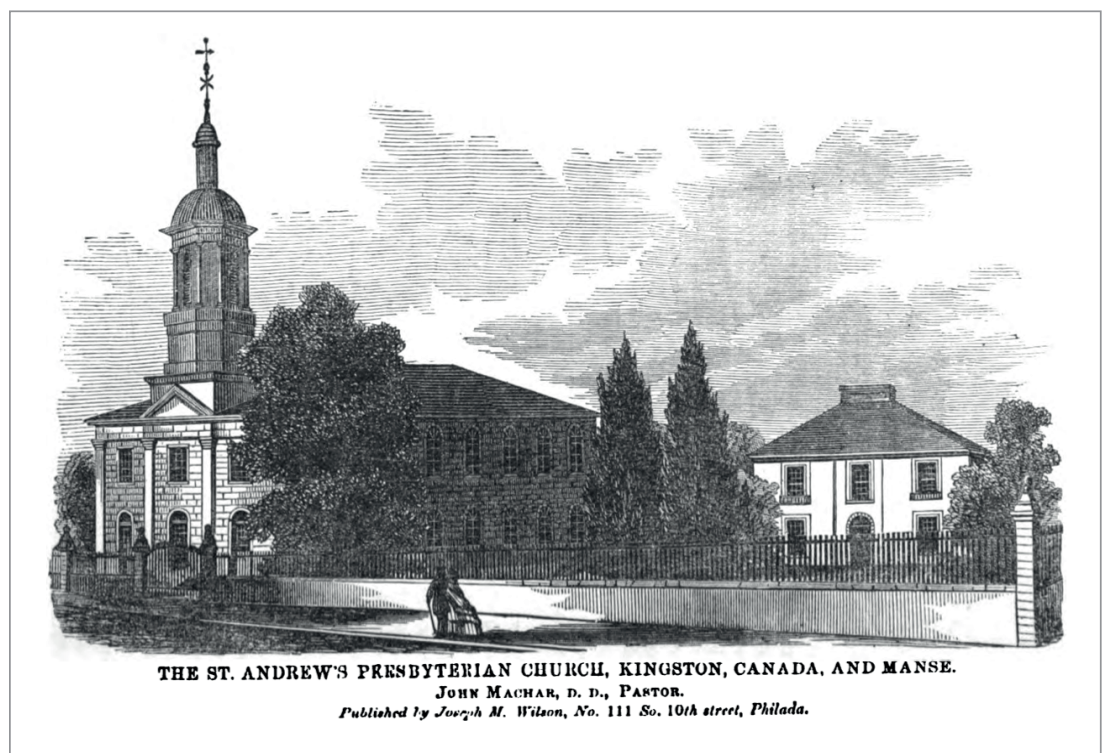

FIG. 3. ST. ANDREW'S PRESBYTERIAN CHURCH, 1861. | WILSON, THE PRESBYTERIAN HISTORICAL ALMANAC, P. 264. example of a wooden church built on simplified classical principles, an "auditory church" designed for the congregation to hear the recited words of the liturgy and the sermon. ${ }^{6}$

At first, music_-probably the singing of metrical psalms in the translation made by Nahum Tate and Nicholas Brady, 1696, A New Version of the Psalms of David, London, M. Clark (and many subsequent editions), with a few hymns addedwas accompanied by the band of the successive British regiments stationed in Kingston. Reverend John Stuart had a long history as the Chaplain of British Regiments, so they may have played without payment during his tenure. Regimental bands continued to provide music after Reverend George Okill Stuart succeeded his father as the incumbent at St. George's in 1811. Since the son had not served as a chaplain, payments were made to the military bands on a regular basis for the next six years, when an organ was installed in a new gallery built for the purpose. ${ }^{7}$ This marked the first move toward greater respectability brought in by the second generation. Five years later, the incumbent and vestry started seriously to consider building a new church. At that time, Anglicans in other parts of the Diocese of Quebec were building more formal and elaborate classical churches of wood. A handsome example from 1827-1828, with some later Gothic Revival additions inside and out, still exists as St. James' Anglican, Hatley, Quebec (fig. 2). ${ }^{8}$ However, the parish of St. George's decided, probably by 1822 , to erect a much more solid and ambitious structure designed by an architect and built with stone.

By the early 1820s, the prosperity and communal ideals of the Anglican community in Kingston, Ontario, couldwith a little help-afford something more expensive. Their modest wooden church had well served a generation of the faithful, including the British garrisons stationed at the local forts and naval base from the late eighteenth century through the war of 1812 and beyond.
With a growing population in Kingston, the first St. George's had become too small, but it also lacked the sophistication needed to meet the expectations of the leaders of an increasingly prosperous and ambitious community. The building of a new classical stone Anglican church in Montreal, Christ Church, which began in 1805, opened in 1814, and finished in 1820, provided a model for what could happen at St. George's, Kingston, on a slightly reduced scale. ${ }^{9}$ A small stone Roman Catholic church had existed in Kingston since 1808 , but the erection of a larger stone Presbyterian church created a seriously competitive situation. The cornerstone for St. Andrew's was laid in 1820; it opened for worship on June 2, 1822, and had the wooden steeple finished in $1823 .{ }^{10}$ The earliest illustration of this church came from 1861, well after the addition of a new, elegant entrance façade in 1837-1838, but it showed that the older walls of the nave consisted of hammer dressed rectangular Kingston limestone with two stories of regularly spaced round-headed windows. ${ }^{11}$ The 
construction of a new stone St. Andrew's Presbyterian Church (fig. 3), with a prominent Anglican layman laying the cornerstone, no doubt made the old wooden St. George's seem even more flimsy, crowded, and less respectable in comparison. The prestigious new St. Andrew's threatened the supremacy of St. George's in attracting the British soldiers and sailors stationed in Kingston to worship. On March 30, 1822, even before the first service took place at St. Andrew's, the vestry of St. George's made an investment and sent a letter to the rector of Christ Church, Montreal, to get ideas for a new building of their own: "Cash remitted with Letter of this date to Revd. John Bethune at Montreal for procuring Plan and Elevation of a Church $f 10 / 0 / 0 . " 12$ The price that they paid indicated either a set of drawings or a copy of those of Christ Church. ${ }^{13}$

The incumbent at St. George's, Reverend George Okill Stuart, had previously served as the Anglican missionary at York, Upper Canada, and had overseen there the construction of the first wooden Anglican church of St. James. After following his father at St. George's and as the official legal representative of the Bishop of Quebec in Upper Canada for a decade, he received a new title for the latter position, Archdeacon of York, in 1821. The challenge of the new stone St. Andrew's, no doubt helped to channel the desire for a larger Anglican church in the direction followed by Holy Trinity Cathedral in Quebec City and Christ Church in Montreal: substantial, solid, stone places of worship built in the classical style. ${ }^{14}$ On this, the Archdeacon and a number of his established, wealthy, conservative parishioners would work together. Only a refined, stone St. George's would better serve their congregation and reflect their perception of the Church of England and Ireland as the bastion of order in a society buffeted by the wars of the American and French Revolutions and the war of 1812.

After their purchase of a "Plan and Elevation of a Church" from Montreal in 1822, the St. George's Vestry must have appointed a Building Committee, for a small sum was voted to be paid in February 1823 for the model of a new church. At the end of March, it resolved to pay the substantial "sum of Twentyfive pounds" to "Charles Robertson for drawings and a small model furnished for a new Episcopal Church." On April $1^{\text {st }}$, the Sexton was voted $£ 3 / 15$ "for his extra attend[in]g during the sitting of the Committee for Build[in]g [a new] Church," and on April 10 ${ }^{\text {th }}$, the sum of twenty five pounds was "paid Mr. Robertson for Model of Church \&c drawings \&c \&c."15 In 1805, "the Crown granted to" Reverend John Stuart "and his church wardens, town lots 122 and 139 immediately south of Block $G$ 'in trust for the purpose of building a parsonage house.'"16 This would be the site for the new church. In preparation for building a substantial church in 1823, Archdeacon "Stuart and his churchwardens George Markland and John Macaulay were petitioning the government for aid in 'erecting a building more suited to the state of the Parish.'"17

When a public subscription did not raise enough funds in 1823, the churchwardens "found the deed of trust limited them to a sum of $£ 1,000$ 'insufficient to erect an edifice ... worthy of the parish.' Therefore, they proposed to surrender the patent and have a new deed issued authorizing a loan of up to $£ 3,000$. This manoeuvre was executed, and a new deed issued in January 1824."18 Archdeacon Stuart, who had a great deal of experience in real estate and managing the lands of his family, "began Renting Block D in 1824."
John Scantlebury, innkeeper, leased for 20 years building lots 17 and 18, on which he must erect within two years "one good substantial building" measuring 71 feet in front, 39 feet wide and 38 feet high, with a brick front. As long as the old Episcopal Church remained on any part of the premises, Scantlebury was to have a rebate in the rent. There were covenants to provide that the building would be kept in good condition and the three trustees had rights to inspect the premises and order work to be done-their own minimum standards committee. At the end of the lease, Scantlebury's building would be evaluated by independent appraisers and he would be paid for it..$^{19}$

Even at this early stage of planning, the ambition of the endeavour had become apparent. On May 17, 1824, the laying of the cornerstone for a new large stone Midland District courthouse, designed by John Leigh Okill (the cousin of Archdeacon Stuart), on the other half of the block where the second St. George's would be built, increased the pressure to take action. ${ }^{20}$

These exploratory moves finally led to a crucial motion passed in a special Vestry Meeting that appointed a Building Committee composed of some of the most prominent Anglicans who lived in Kingston:

At a Special meeting of the Pew-holders and Parishioners on the $9^{\text {th }}$ April 1825A. McLean Esq. in the Chair, the following Resolutions proposed by R. Stanton Esq. were unanimously adopted.

That a subscription Paper be opened immediately and circulated in aid of the Funds for building a new Church. The amount of Subscriptions to be payable by instalments as follows, one third on the $1^{\text {st }}$ December 1825 , one third on the $1^{\text {st }}$ June 1826 , and 
the remaining third on the $1^{\text {st }}$ December 1826.

That the amount loaned and subscribed be appropriated together with the Sale of Pews when the Church is finished, to the erection of a Protestant Episcopal Church in the Town of Kingston on the Lot granted for that purpose.

That the following persons be a directing Committee for carrying the Resolutions passed at this meeting into effect:

The Hon ble G.H. Markland

Thomas Markland Esq

C.A. Hagerman Esq.

John Macaulay Esq.

John Kirby Esq.

That a Secretary and Treasurer be appointed to the Committee. It shall be the duty of the Secretary to attend all meetings of the Committee and keep a Journal of their proceedings - to keep the account and draw Checks for payment of money by their order on the Treasurer. It shall be the duty of the Treasurer to receive and have in safe keeping the funds appropriated for the erection of the Church, and to make payments by Checks drawn on him by the Secretary by order of the Committee and to keep a statement of the same.

That the Committee without delay enter into an agreement with an Architect or Architects for the erection of the Building within two years from the date of agreement. The Architect or Architects to provide all materials and to erect the Building according to a Model, furnishing Sureties to the satisfaction of the Committee for the due fulfillment of his or their agreement. The payments on this agreement to be regulated by the judgment of the Committee.

That as soon as the Church is completed according to agreement the Committee do report to the Pew-holders and Parishioners who shall make such arrangements as may be necessary for selling the Pews.

That the Secretary and Treasurer to respond annually to the Pew-holders and Parishioners at Easter meeting the proceedings of the Committee and the state of the Funds for their information and satisfaction.

That James Nickalls Esq. be appointed Secretary and David J. Smith Esq. be Treasurer.

That the Resolution passed at this meeting be signed by the Chairman and delivered to the Church Wardens for the purpose of being entered by them in the Parish Books and that a Copy of the Resolution be delivered to the Committee. ${ }^{21}$

The members of this Committee had strong involvements in business, law, the militia, and politics in Kingston and many of them in York, the capital of Upper Canada. They "personified the post-war image of the Anglican congregation at Kingston. These affluent and elite men were firmly committed to the conservative and Tory ideologies of the new Upper Canadian leadership."22 They had strong connections with the Lieutenant Governor, Sir Peregrine Maitland, an officer in the British army during the wars against Napoleon who strongly believed in the Church of England and Ireland as a bulwark of order. ${ }^{23}$ The secretary of the Committee held the important position of clerk of the Land Board for the Midland District. All treasured the British connection of the Church of England and Ireland and saw an impressive new church as upholding and extending British order in Canada.

The Committee wasted no time. By the time of its first recorded meeting on April 15, 1825, it had hired the Kingston architect Thomas Rogers to draw up plans for the new church and "Mr. Rogers produced his amended plan which after some amendment was adopted; and Mr. Rogers was ordered to prepare specifications by Wednesday next at Twelve $\mathrm{O}[$ ']C[loc]k, to which time the Committee adjourn[ed]."24 On Wednesday, April 20, 1825, "Mr. Rogers submitted another plan: which was after some modifications adopted; a notice for tenders given of the following effect." 25 The lot on which to build the new church was granted to the Rector and Wardens of St. George's in 1825 , but even before then the Building Committee began to work on the building. ${ }^{26}$ They advertised for stone masons and carpenters to send in tenders, laying out their bids to construct a church from the architect's design. In early May, the Committee held two meetings on successive days to examine the tenders. At the second meeting, with "John Kirby, John Macaulay, Thomas Markland, and C.A. Hagerman" present,

\footnotetext{
The several tenders were Examined-Those of Rowland Hough as Masons and Millan and Wallace as Carpenters-jointly-and of Matthews \& Lauder as Masons, and John Corry as Carpenter were the two lowest tenders, but from the circumstances of their being both higher than the amount of the disposable funds under the controul [sic] of the Committee: the parties were informed that they must revise their Tenders and give them in amended tomorrow at Twelve O[']CI[oc]k at noon. ${ }^{27}$
}

On the following day, with the same men present, "and after some discussion the Tenders of Robert Matthews and Andrew Lauder, for the Masonry work, and of John Corry, for the Carpentry work, were accepted," the masons for $f 1,70112 \mathrm{~s}$ and the carpenters for $f 1,188 \mathrm{7s} 4 \mathrm{~d}$ "and the contracts ordered to be made out"; the final contracts, with sureties, were signed on May 26, $1825 .{ }^{28}$ Four days later 
after the carpentry contractor asked an advance

for the purpose of the purchase of materials, the Committee conceiving that it is a matter of the greatest importance that the wooden materials should be obtained immediately, that they may be seasoning: Resolved that the sum of two hundred and fifty pounds be borrowed and placed in the hands of the Treasurer, to be advanced to the contractor John Corry upon his producing, an indorsed note with two indorsers, payable to the 20: Nov. 1825-and to be considered as an advance separate from the contract-

The meeting adjourned. ${ }^{29}$

With funds already borrowed and committed, the Building Committee quickly decided to try one more avenue for raising funds, a grant from the Crown.

In a long petition sent to Lieutenant Governor Maitland, they described the project of building the new stone St. George's, Kingston, mentioned the $£ 3,500$ that they had already raised through subscription and a loan, and stressed that their "solid and durable" church must also "be respectable in size and appearance, ornamental to the town, and worthy of the Venerable Establishment to which they feel a just pride in belonging." 30 The conservative men of Kingston picked words that not only represented their own point of view, but also would appeal, as they knew, to the Lieutenant Governor, an equally conservative former subordinate of the Duke of Wellington in Spain, at Waterloo, and in Paris. Noting that they had designed a large church, in part to have pews for the British military serving in Kingston and that the "portico and steeple" in the plans would cost between " $f 1,200$ or $f 1,500$ " above the funds that they had raised, they also drew attention to the precedents that "in similar cases the churches at Quebec and Montreal have been assisted by the Government." ${ }^{31}$ On June 1, 1825, the Committee sent their petition to the Lieutenant Governor, along with "a copy of the Plan and Elevation of the contemplated building" to demonstrate how the new St. George's would become more "respectable in size and appearance" than any other Anglican church in Upper Canada. ${ }^{32}$

Looking forward to the laying of the cornerstone of the new St. George's, the Committee invited the "Master of St. John Lodge of Free Masons No. 5" on June 11, 1825 , to participate in the ceremony, as he had at St. Andrew's Presbyterian Church, Kingston, in 1820, explaining that the Lieutenant Governor would arrive in Kingston to grace the event. ${ }^{33}$ "His Excellency the Lieut. Governor having been requested to lay the corner stone of the church was pleased to appoint Monday the twentieth day of June 1825." ${ }^{34}$ The ceremony largely mirrored that at laying the cornerstone for St. Andrew's Presbyterian Church in 1820, as described in the Kingston Chronicle. ${ }^{35}$

In 1825, however, "the requisite authority for acting" by the Free Masons had not arrived "from York" to allow them to perform their role when Lieutenant Governor Maitland instead of a local magistrate laid the cornerstone, so portions of the ceremony changed. ${ }^{36}$

On June 20, 1825, at 11 a.m., "the Committee, assisted by Mr. John Morse as the Marshall of the day, arranged the procession which set out from Mr. Walker's Hotel, to the building: preceeded [sic] by the Band of the 37. Reg[iment,]" it included the "Architect, Builders, Sexton, Clerk, Church Wardens, Building Committee, Staff of the Garrison, Clergy Barristers, Physicians, Sheriff, Magistrates,
Members of Parliament, Military and Naval Officers, and Gentlemen".37

The Procession, on reaching the foundation [of th] Church, formed around it, and in the mean while two members of the Building Committee met his Excellency at the Government wharf, and conducted him to the platform near the eastern corner of the Church, where [he] was received by the Band and Guard with [Mi]litary Honours. The Venerable the Arch[dea]con invoked a blessing on the act about to [be] performed by His Excellency-after which [the] stone was lowered and adjusted in its place, [dur]ing the performance of solemn music. A hammer was next presented to the Lieutenant Governor, who went through the ceremony usual on such occasions, and the Archdeacon concluded with another appropriate prayer. The Procession, in which His Excellency joined, then retraced its steps to Walker's Hotel, where refreshments were provided under the directions of the Committee. ${ }^{38}$

Two days later, the secretary of the Building Committee sent a letter to the Master of the Kingston Masonic Lodge, a member of St. George's:

The Committee notwithstanding the delay which had occurred in the transmission from York of the requisite authority for acting would have been perfectly well inclined to wait its arrival, had they not previously solicited the Honor of the Lieut. Governor's presence on the occasion, and found that in consequence of His Excellency's short stay in town, they could not postpone the ceremony. ${ }^{39}$

For the prominent, businessmen, lawyer, and politicians who sat on the Building Committee of the second St. George's "Protestant Episcopal Church," the importance of the prestige involved in having Honourable Lieutenant Governor 
Maitland lay the cornerstone of what would become the largest and most substantial Anglican church in Upper Canada clearly outweighed having the Masonic rites performed on the occasion. The ceremony became an even more prestigious civil event than in 1820 , with a small religious component, rather than the religiously focused events that the laying of the cornerstones of Anglican churches would become later. ${ }^{40}$

During the summer and autumn of 1825 , work on the new St. George's went well. On September 8, the Committee gave authority to the Treasurer to draw $£ 300$ from the "account of the loan to the Church," and on the same day $f 15$ was paid "to Tho. Rogers in account of his Salary" for supervising the construction. Nine days later, $f 120$ was paid to "Messrs. Matthews and Lauder, to compleat [sic] their second payment." 41 This indicated that the architect and masons had carried out a great deal of work on the walls of the church during the spring and summer.

On December 6, 1825, Archdeacon Stuart included a lengthy discussion on the erection of the new St. George's in his annual letter to the Society for the Promotion of the Gospel in Foreign Parts, noting:

among the favourable occurrences of the past year is the erection of a new stone Church in Kingston, which is now in a state of progressive advancement and will be finished in the course of one year from the date of his letter. It is 87 feet long \& 55 feet wide, with a projection of 8 feet to the length in front, forming the base of the steeple. The height, including the cornice, is 35 feet 6 inches. It is the opinion of those who are conversant in Architecture that this new edifice will be inferior to the Cathedral at Quebec only in dimensions, \& that, with respect to its model and proportions, it may be considered the third best edifice in the Canadas. His Excellence, Sir Peregrine Maitland, Lt. Governor, laid the corner stone on the $9^{\text {th }}$ of July last, assisted by the Archdeacon of York, who officiated at the accustomed solemnities of Benediction and Prayer. ${ }^{42}$

This letter provides important information on the size and configuration of the new stone church, which the Archdeacon rated as only behind Holy Trinity, Quebec, and Christ Church, Montreal, as the best edifices "in the Canadas." The walls seem to have reached their projected height and work had progressed on the base of the projected steeple.

In this letter, Archdeacon Stuart also included information on the financing of the work and a request for additional help from the Society for the Advancement of the Gospel in Foreign Parts:

\footnotetext{
The contemplated expense will amount to $£ 5,000$ Halifax currency, \& in order to pay this debt the Committee are supported by a Subscription Paper of $£ 1,400$ \& a Ioan of $£ 2,000$, whose Interest \& the Principal are to be repaid in the lapse of years from rents payable to the Committee, who are trustees, holding an acre of land in the town of Kingston for that purpose granted by the Lt. Governor. ${ }^{43}$
}

He suggested that the Society might like to make a donation to help provide the additional $f 1,600$ needed to complete the work.

In a meeting of the Building Committee on December 24, 1825, attended by "Thomas Markland, John Kirby, John Macaulay, H.A. Hagerman Esquires," a number of important resolutions were passed. First: "It was resolved that the offer of Thomas Blackwood for plastering the church be accepted which is for the sum of Two
Hundred and Twelve pounds, ten shillings, agreeable to the specifications," with three payments to be made "upon the certification of the superintendant [sic], of the progress of the work." 44 The walls, windows, and roof of the building would have had to be in place before plastering could begin. Second, they accepted "the offer of Mr. Corry to put up the wood work for the groining of the arches," for $\mathrm{f20}$; these would provide support for the roof. Third, they agreed with "the offer of Mess. Lauder \& Matthews to carry up the tower about fifteen feet, to the top of the cornice (beyond their present contract): provided they will be agreeable to the specification," for $£ 185$. Fourth, "Mr. Rogers having produced his account amounting to $f 87.15 .6$, deducting f35. already paid," it was agreed to pay him f52.15.6 "by the Treasurer without delay," and noted that his wages for superintending the construction during the following period up to September 1, 1826, would amount to $f 83 .{ }^{45}$ Putting up the walls and possibly the roof of the new church during the working months of 1825 marked a major accomplishment.

It would take nearly two years from the writing of Archdeacon Stuart's letter, in early December 1825, before the second St. George's opened for worship. Apart from finishing the "steeple", most of the remaining work needed to take place in the interior of the structure, the giant fluted Ionic columns that helped to support both the galleries and an Ionic entablature that supported the roof had probably been installed. The walls and ceilings needed to be plastered, the pews in the nave, pews at the front and chancel end of the side galleries and the open seating at the back of the galleries built, the organ moved from the old church to the new and installed, a pulpit built for sermons and a reading desk from which the parish clerk would join the minister 
in reading the services from the Book of Common Prayer, a communion table, and chairs for the clerk and clergy who would lead worship from the front of the apse. ${ }^{46}$

On July 11, 1826, the Building Committee had received a letter through the Lieutenant General of Upper Canada noting that the Crown had agreed to provide $f 1,500$ toward the cost of building the new St. George's. On July 15, 1826, when work on the tower had reached the fifth stage, members the Building Committee, flushed with additional funds, agreed to a proposal by the architect to make the portion of the tower that would hold a clock look more refined:

\footnotetext{
Mr. Rogers the superintendant [sic] having suggested the propriety of having an alteration, of . . Double Pilasters, instead of single ones, in the part of the steeple, now erecting: and Messrs. Lauder and Matthews having agreed to perform the work as suggested for thirty pounds in addition to the present sum for one hundred and eighty five pounds. It was resolved that their offer be taken and that Double Pilasters be made instead of the single there; making the whole sum now to be paid two hundred and fifteen pounds. ${ }^{47}$
}

However, by August 1, 1826, the date for completion of the carpentry work on the new church, it was apparent that John Corry had not yet fulfilled his contract, so he was sent a letter by the secretary of the Building Committee informing him of the consequences.

I am directed by the Committee for superintending the erection of the Protestant Episcopal Church of Kingston to notify you that in consequence of the said church not being completed this day according to your contract with them, they will look to your sureties for any damages that may accrue from such non-performance. ${ }^{48}$
Several attempts were made to enforce Corry and his sureties to complete the work, but these met with very little success.

While work continued, the "Honourable and Right Reverend Charles James Stewart" visited Kingston on September 18 and 19, 1826, three months and twelve days after his ordination as the second Bishop of Quebec in Holy Trinity Anglican Cathedral, Quebec City. After congratulating him on his earlier position as "Traveling Missionary for the Diocese" and for his "assistance in the arrangement for obtaining a supply of tracts from the Society for Promoting Christian Knowledge," Archdeacon Stuart said: "our confidence in your Lordship's ability and zeal to carry into effect all such plans as in your wisdom and under the Divine Blessing will diffuse Christianity, and subserve the temporal and eternal interests of the people of this Colony . . ."49 $\mathrm{He}$ went on to express:

\footnotetext{
our deep regret that we are at present without a place of worship of our own in which your Lordship might discharge the sacred functions of your holy office. We, however, hope that the edifice now erecting and towards the completion of which our Gracious Monarch has deigned to favour us with his munificent aid, will be in readiness for your reception, when we shall next have the satisfaction of beholding your Lordship among us. ${ }^{50}$
}

The new bishop, who knew Archdeacon Stuart and his father well, had clearly viewed the work already done on the second St. George's and expressed his future vision of the completed church:

I congratulate you upon the prospect of possessing an edifice for public worship at once so commodious for the sacred purpose to which it is to be dedicated, and so ornamental to the town; and, while I look forward with pleasure to my next visit, when arrangements may be made for the consecration of the church, we have the less reason to lament our present temporary inconvenience. ${ }^{51}$

With the elegant limestone exterior of the second St. George's nearly finished, Bishop Stewart could afford to flatter his hearers by commenting about how "commodious" and "ornamental" it was, but he also promised something that his predecessor had only done once during his relatively lengthy tenure, the "consecration" of a completed church.

Work proceeded on the tower, with the Building Committee signing a new contract with Matthews and Lauder to build the stage that would hold the bell on August 5 for which they received payments on September 7, October 6, and November 11, $1826 . .^{52}$ Finally, on October 6, 1826, the Building Committee faced the fact that "Mr. Corry having declared himself unable to carry on the carpenter Work unless he receive a further advance of money-and Mr. Atkinson one of his Sureties having made a similar declaration" and "there being no progress actually making with the said work," they ordered Rogers to "take an Inventory of the Carpenters and Joiners Works, actually executed within the Church, as well as the materials and work in the state of preparation on the contract" and when they received his report, they finally decided on October 10, 1826, that:

The Contractors for compleating [sic] the Joiners and Carpenters Work of the church having failed to perform their agreement, it was resolved that the Committee with themselves have the work finished under the direction and the supervision of Mr. Rogers, by men to be employed and paid by them. ${ }^{53}$ 


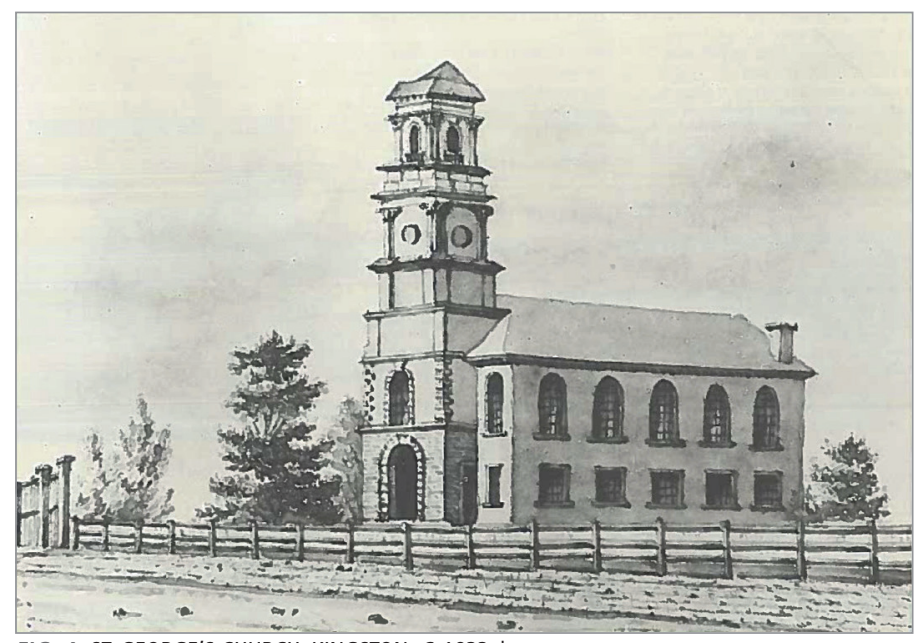

FIG. 4. ST. GEORGE'S CHURCH, KINGSTON, C. 1833. | ALODI, CANADIAN WATERCOLOURS AND DRAWINGS IN THE ROYAL ONTARIO MUSEUM, NO. 2271

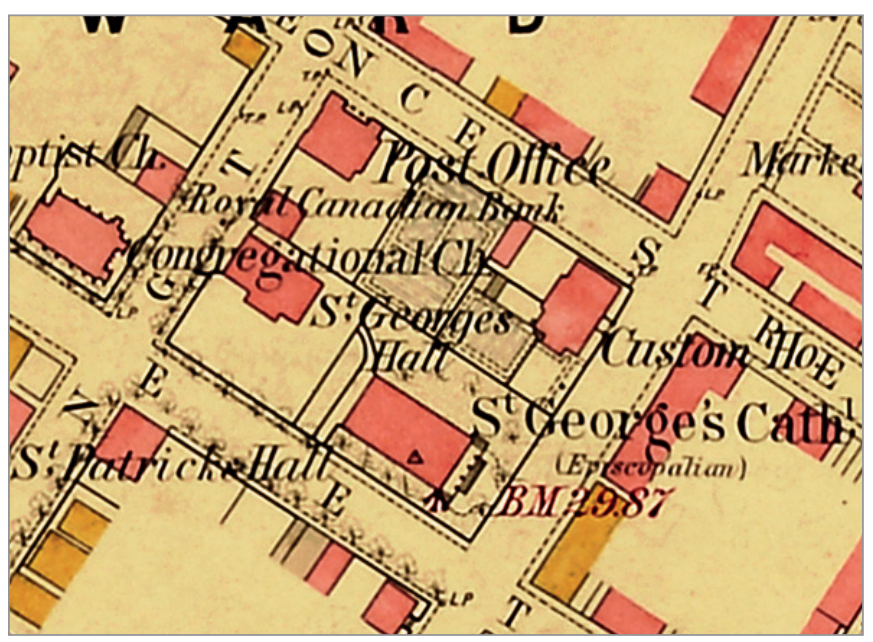

FIG. 5. CORNER OF JOHNSON AND KING STREETS ON ORDNANCE SURVEY MAP OF KINGSTON, 1869. WO 78-4869-2 SHEET III PL XIV. | COURTESY OF JENNIFER MCKENDRY.
Mathews and Lauder received a further contract on February 21, 1827, "to build the turrets on the Tower and the platform and steps in front of the Church" for $f 200$ for the former and $£ 230$ for the latter and "direct that the "superintendant [sic] make out the specifications" for these jobs, which were to be finished by June 20 and July 15, 1827. ${ }^{54}$ The stonework would soon be finished, but the failure of the original carpentry contractor set back the completion of the interior of the church for more than another year.

Apart from the contracts signed with the masons in February 1827, the Minutes of the Building contain no further information on the other work carried out inside the shell of St. George's from October 1826 onward. The Vestry Minutes from 1826 to 1834 are not available, so it is difficult to track the completion of the interior of the second St. George's. Enough work on the interior had taken place by March 1826 to advertise the sale of the first St. George's in the local newspapers and to have the organ removed from it. ${ }^{55}$ Despite the difficulties caused by the inability of Corry to complete his contract for the carpentry work in 1826 and the cost of hiring other artisans to finish the work, the second St. George's finally opened for worship on November 25, 1827.

Four contemporary artistic depictions of the exterior of St. George's, along with the surviving fabric, and the minutes of the Building Committee and the Vestry provide considerable evidence for appearance of second St. George's. A large, but incomplete portion of the architect's elevation for the ritual west façade probably dates from 1825. It included two detailed watercolour depictions of different versions of the tower, but a tear in the paper has removed Rogers's design of the tower on the left side and the top three stages of the tower on the right. ${ }^{56}$ A watercolour and ink painting by James Pattison Cockburn (1829) and a pencil, sepia and grey wash view of Kingston from the water by Charles Frederick Gibson (c. 1832), British officers stationed in Kingston, contain incomplete images of St. George's within larger views of downtown Kingston. ${ }^{57}$ A small anonymous pencil drawing with brown wash of the ritual west and north façades (c. 1833), in the collection of the Royal Ontario Museum (ROM), provides an overall view of the church alone (fig. 4). ${ }^{58}$ While none of these contain all of the details in Rogers's elevation, Cockburn's is the most detailed. Collectively they provide views of three of the façades of the church as built. Maps of Kingston from 1850 onward provide images of the footprint of the church. Portions of the Minutes of the Building Committee and the Vestry, and letters to the Lieutenant Governor of Upper Canada and to the Society for the Propagation of the Gospel in Foreign Parts have already been quoted and cited above. The first three bays of the exterior walls from 1825 , with a change in the fenestration, survive in the stonework from three bays on the ritual north and south exterior walls of existing nave. No known visual records of the ritual east façade have survived, but footprints of St. George's on maps portray it as a plain wall, without an external apse (fig. 5). ${ }^{59}$

The material, visual, and verbal sources reveal that the second St. George's boasted walls constructed of large blocks of ashlar, including a regular five-bay nave, "lit by two ranges of small pane windows. The windows on the upper range were tall and topped by rounded 


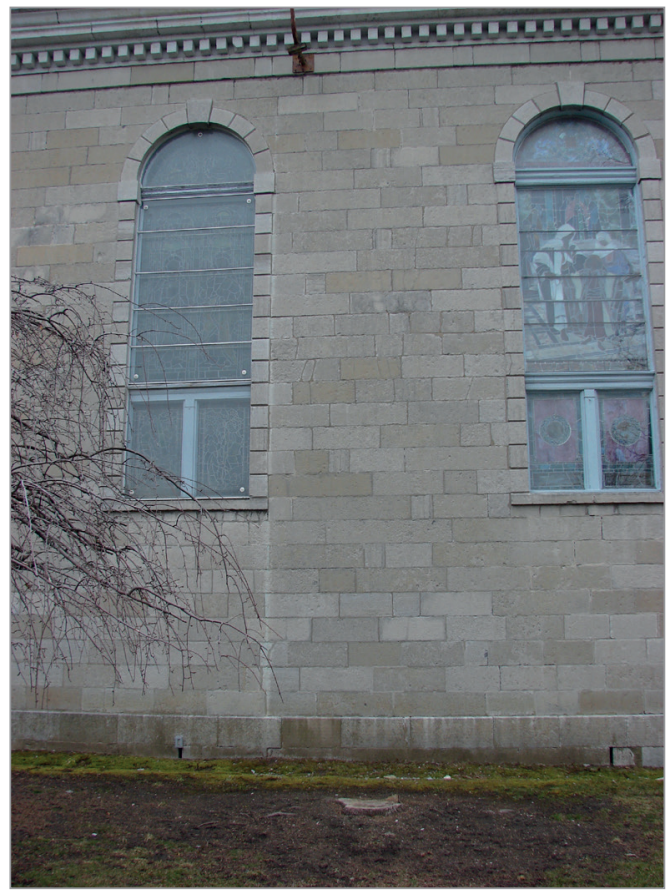

FIG. 6. TWO MODIFIED NAVE WINDOWS AND STONE WALL FROM THE SECOND ST. GEORGE'S ANGLICAN CHURCH. | PAUL CHRISTIANSON, JANUARY 2020.

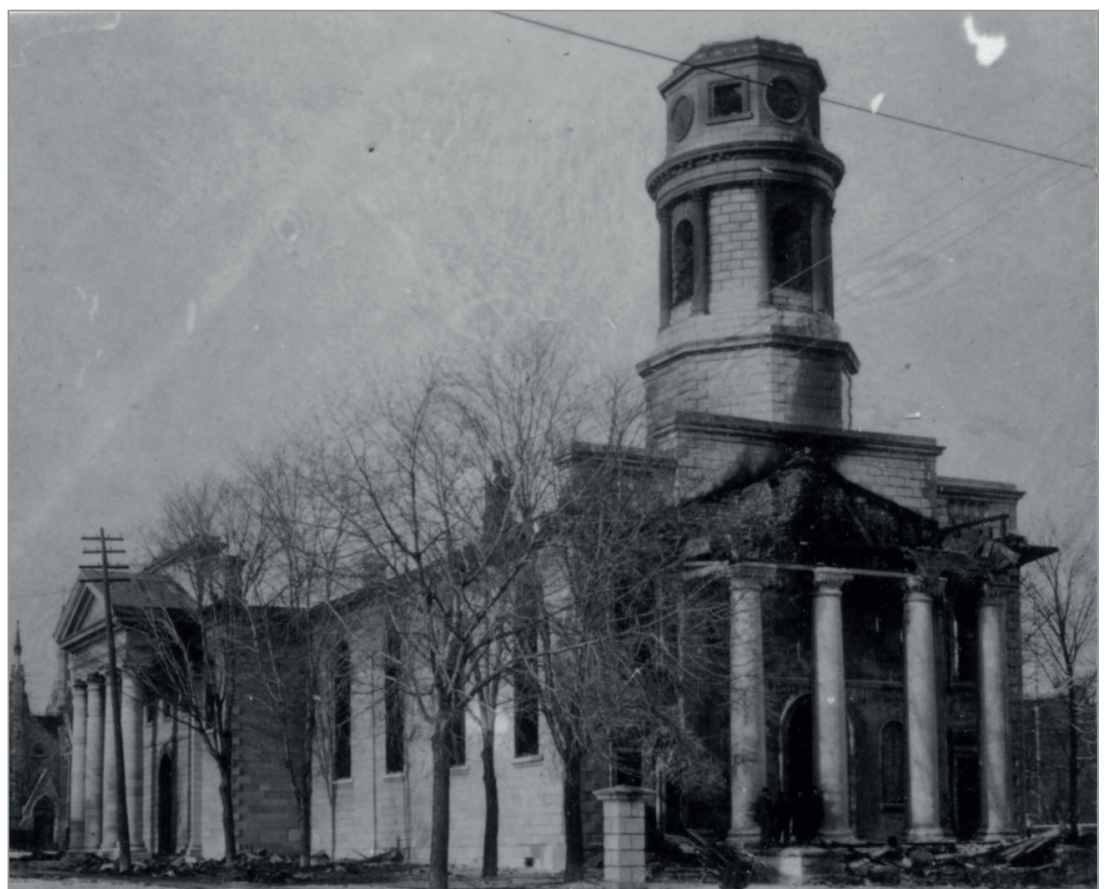

FIG. 7. ST. GEORGE'S CATHEDRAL, KINGSTON, AFTER THE FIRE OF 1899. | QUEEN'S UNIVERSITY ARCHIVEs, KINGSTON PICTURE COLLECTION, V23-RELB-ST. GEORGES CATHEDRAL-6_6. arches, while those on the lower range were square." 60 The surrounds consisted of smooth, rusticated stones slightly raised above the wall surface, with even larger smooth, elevated stones that marked a transition from the straight sides to the arched heads and prominent, slightly elevated keystones. These details gave life to the outside of the windows. ${ }^{61}$ During the additions to St. George's in 1891, the lower rectangular windows were extended upward to join with the upper ones and the stonework beneath them reworked, so the lower part of the existing window openings differ from the originals (fig. 6). The upper portion of the walls had a string course of ashlar that acted as a frieze and gave a horizontal emphasis just below the dentils. Above the dentils sat the projecting cornice. These features appeared on the elevation drawn by Thomas Rogers in 1825 , on contemporary views by British officers, and still exist on the sides of the building (except for the cornice which was destroyed in the fire of 1899; see fig. 7). They also exist on the ritual north façade and probably existed on the ritual east façade. Although distinctive quoins graced the corners in the elevation by Rogers, only Cockburn started to sketch them in on the upper part of the ritual west façade, but they were shown clearly at the east and west ends of the ritual south wall on a drawing of St. George's from c. 1842. ${ }^{62}$ Since Rogers supervised the construction of the building, it was probable that he included quoins at all four corners of the nave.

The ritual east façade featured a large, tall window with a rounded top, probably originally glazed as a single window divided by muntins into three sections, like that designed by Rogers for the stone, classical Anglican Church of St. James built in Toronto in $1831 .{ }^{63}$ The curving walls shown in the interior photograph of St. George's (fig. 8) denoted an interior apse similar to those at Holy Trinity Cathedral, Quebec, and the cross section and floorplan for St. James, Toronto, drawn by Thomas Rogers (figs. 9 and 10). There were probably similar, but smaller rooms entered by doors at the end of side aisles at St. George's. ${ }^{64}$ The carefully composed exterior of the second St. George's had walls of large rectangular grey ashlar limestone blocks, five uniformly sized and spaced windows along the ritual north and south façades, and a large chancel window on the east. Above the windows was an lonic entablature consisting of a plain frieze, dentils, and a projecting cornice. The combination of these understated elements created a refined classical structure.

The elevation of the ritual west façade by Rogers included the basic elements of the other three facades, but also added new details, especially on the tower. On both 


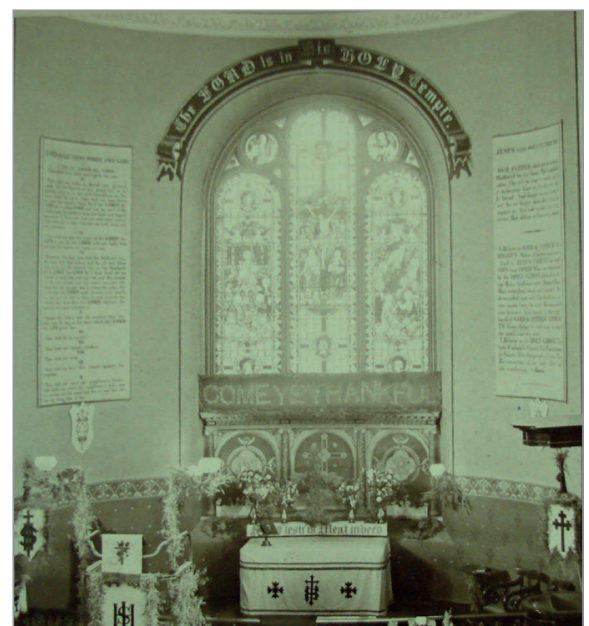

FIG. 8. PHOTOGRAPH OF THE INTERIOR APSE OF ST. GEORGE'S BETWEEN 1874 AND 1891. | swAINSON (ED.), ST. GEORGE'S CATHEDRAL, P. 32, FIG. 1.

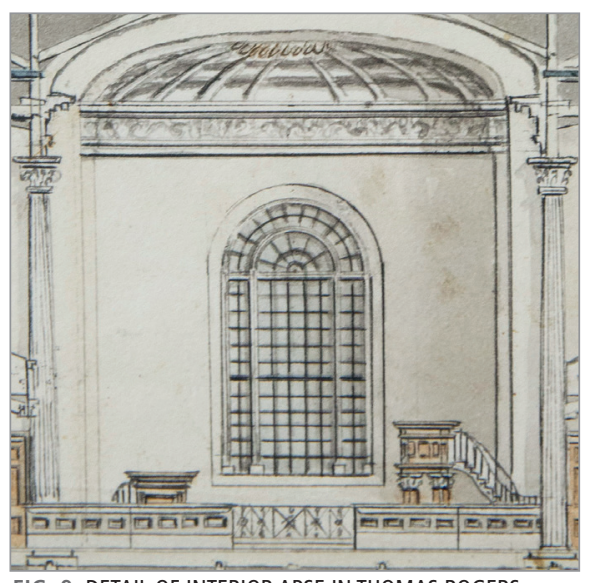

FIG. 9. DETAIL OF INTERIOR APSE IN THOMAS ROGERS, CROSS SECTION FOR ST. JAMES, TORONTO, 1831. ARCHIVES OF THE CATHEDRAL CHURCH OF ST. JAMES, TORONTO, DETALL OF PHOTOGRAPH 20200122_166.

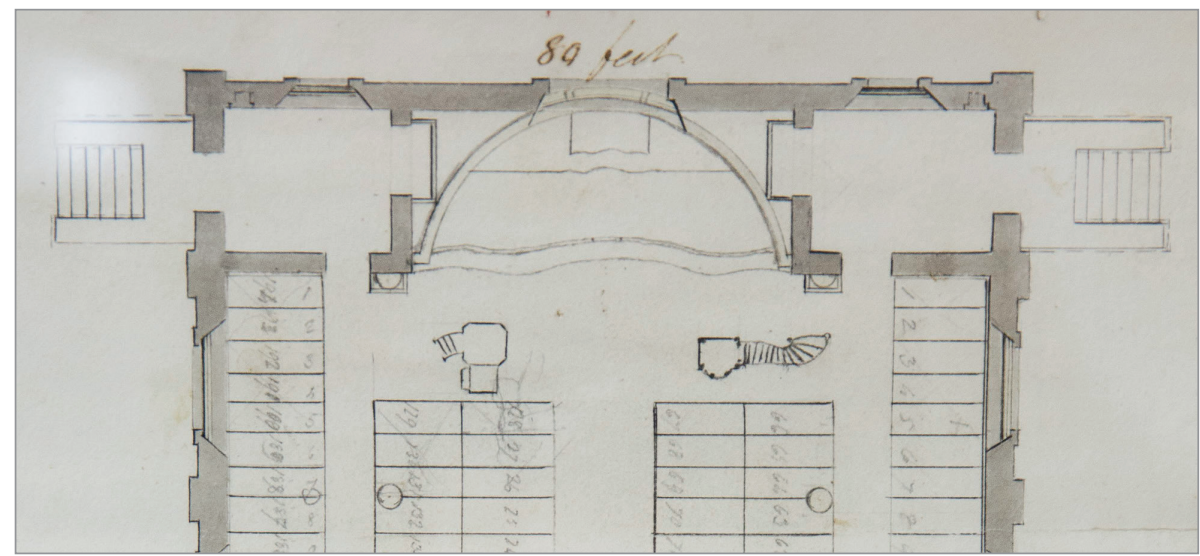

FIG. 10. DETAIL OF INTERIOR APSE IN THOMAS ROGERS, FLOORPLAN OF ST. JAMES, TORONTO, 1831. | ARCHIVES OF THE CATHEDRAL CHURCH OF ST. JAMES, TORONTO, DETAIL OF PHOTOGRAPH 20200122_174.

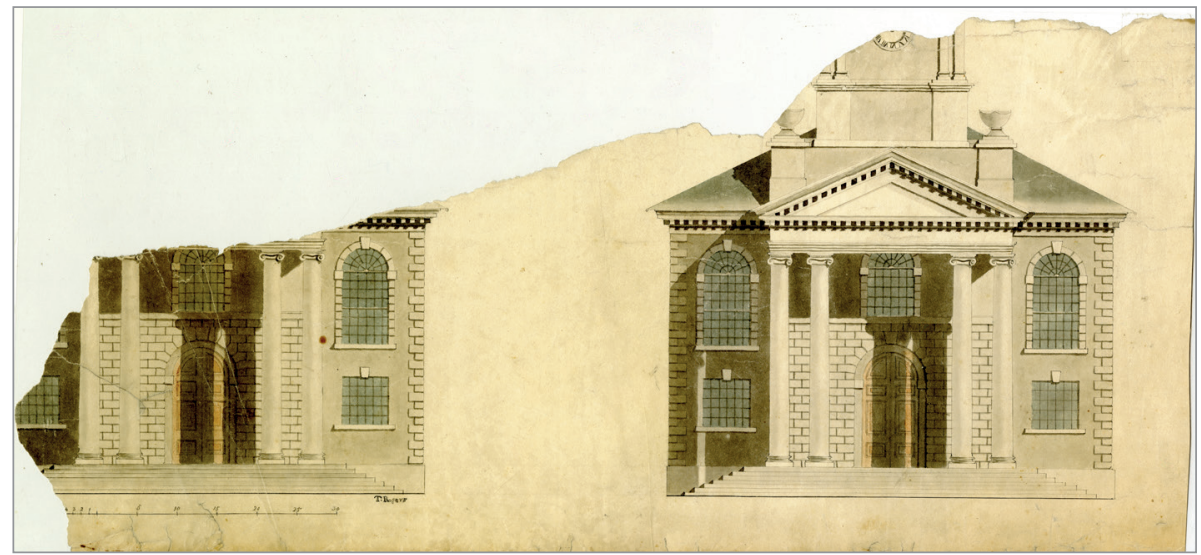

FIG. 11. THOMAS ROGERS, DESIGN FOR THE ENTRANCE FAÇADE OF ST. GEORGE'S ANGLICAN CHURCH, KINGSTON, UPPER CANADA, C. 1825. | QUEEN'S UNIVERSITY ARCHIVES KINGSTON ARCHITECTURAL DRAWINGS-6.

Holy Trinity, Quebec, and Christ Church, Montreal, the towers with their James Gibbs derived spires stood behind the plane of the west façade. The elevation by Rogers depicted an entrance façade of three bays, with a central tower that projected in front of the walls of the side bays (fig. 11). As a whole, the elevation showed "a grand tetrastyle lonic portico set against a tower of several stages, a clock" and a belfry, plus two side bays that duplicated the windows, plain frieze, and dentils of the north and south façades with quoins at the corners. ${ }^{65}$ The first three stages of the tower did not balance horizontally with the side bays, as seen by comparing the tall, arched opening for the door in the west face of the tower with the shorter square windows on the side bays and the truncated arched window above the door with the tall, arched windows on the side bays. The top of the first stage of the tower reaches above the bottom of the upper windows on the side bays, as well. In the elevation, the lonic portico had columns that sat on mounded bases and supported three-foot-wide capitals and an entablature with a plain frieze and dentils under a projecting cornice. ${ }^{66}$ The portico was portrayed as resting on a large raised stylobate with steps on three sides. ${ }^{67}$ The lonic tetrastyle portico was never built, however, so the less than balanced nature of the lower part of the elevation became more glaring. In their portrayals of the built second St. George's, the British officers incorporated most of the details-including the stylobate-shown in the elevation by Rogers except for the portico which had not been erected.

Rogers put a good deal of thought into his depiction of the elevation of the tower. The tops of all except the third stage were marked either by a string course, a moulding, or a cornice as seen not only in his elevation, but also in the 


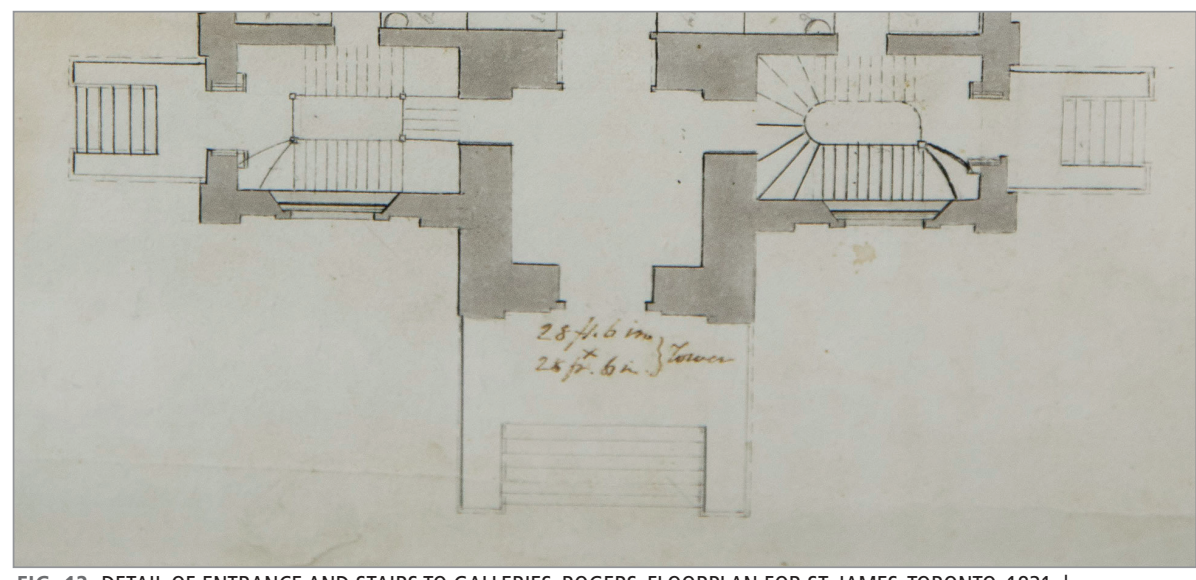

FIG. 12. DETAIL OF ENTRANCE AND STAIRS TO GALLERIES. ROGERS, FLOORPLAN FOR ST. JAMES, TORONTO, 1831. | ARCHIVES OF THE CATHEDRAL CHURCH OF ST. JAMES, TORONTO, DETAIL OF PHOTOGRAPH 20200122_174.

contemporary representations of the building. The lowest stage of his elevation showed a central entrance with a smooth ashlar surround. However, the portrayals of Cockburn and the ROM artist both show a door surround laid in courses of smooth rusticated stones like those around the arched windows on this façade. Since Rogers did use monolithic blocks of limestone on the door surround at Knaresborough Cottage (1834), he may have done so at St. George's. ${ }^{68}$ Rogers also showed smooth rusticated stones laid in even courses on the walls of the first stage of the tower, except for those mimicking voussoirs over the arched portion of the surround. The wooden double doors closed to form a rounded top. ${ }^{69}$ The smooth rusticated stonework provided a clear contrast with the ashlar of the flanking walls and the upper stages of the tower. Rogers, Cockburn, and Gibson show a string course at the top of the rusticated portion. Rogers and Cockburn portrayed the rustication in detail, but the ROM sketch showed it faintly, although perceptibly.

On the ritual south side of the first stage of the tower, Cockburn drew a tall, rectangular opening that resembled a window and on the ritual north side, the
ROM sketch showed an opening of similar proportions that looked like a door. Many churches at that time had exterior doors leading to stairs to the galleries, including Rogers's design for St. James, Toronto (fig. 12). ${ }^{70}$ That seems likely for the second St. George's, but none of the sources describe the configuration of the interior of the tower.

Serious problems with the stability of the tower less than five years later suggest that Rogers had not designed and built thick enough walls on the first three stages of the tower to support a tall tower. With one central door, worshippers would need to access both the side and central aisles by separate openings on the main floor on each side of the tower inside the nave. With exterior doors in the sides, a tower extending eight feet beyond the exterior and interior of the nave wall would have given interior space for a five- to six-footwide set of stairs to the galleries. ${ }^{71}$

The second stage of the tower had ashlar walls and a central arched window above the entrance that had the same width and surround as the upper windows in the side bays of the façade, but was noticeably shorter in length. ${ }^{72}$ The ROM sketch portrayed both corners on the ritual west face of this stage of the tower as having quoins, while Cockburn included quoins on only one corner. Rogers may have intended to have quoins here, but it could have been difficult to show them on his elevation because of the width of the columns on his portico. The built stage probably included them.

The plain frieze, dentils, and cornice of the side walls of the nave continued around to the outside bays of the ritual west façade (and around the portico on Rogers's design). However, as built and portrayed by the British officers, a string course of ashlar without dentils marked the top of this stage on the tower. Since the tower as built projected eight feet in front of the plane of the nave walls and did not have a cornice or a portico, it posed a difficult design problem. The third stage of the tower had the same width, but less height than the first two. Made of ashlar, it had raised sections at the corners that in Rogers's elevation drawing acted as slightly stepped bases for vases. This feature, minus the vases, appeared in detail in Cockburn's watercolour (fig. 13) and, less clearly, in the sketches by Gibson (fig. 14) and the anonymous ROM artist. The fourth stage initiated the smaller, square base of the upper reaches of the tower. Rogers and the officer artists showed it as reaching near the peak of the roof and having raised sections on all sides. ${ }^{73}$ All of the upper four stages had prominent mouldings or cornices at the top.

The fifth stage had double pilasters at the corners of each side and a central location for a clock face on a smooth stone plane on all four sides.

Mr. Rogers the superintendant [sic] having suggested the propriety of having an alteration, of . . . Double Pilasters, instead of single ones, in the part of the steeple, now 


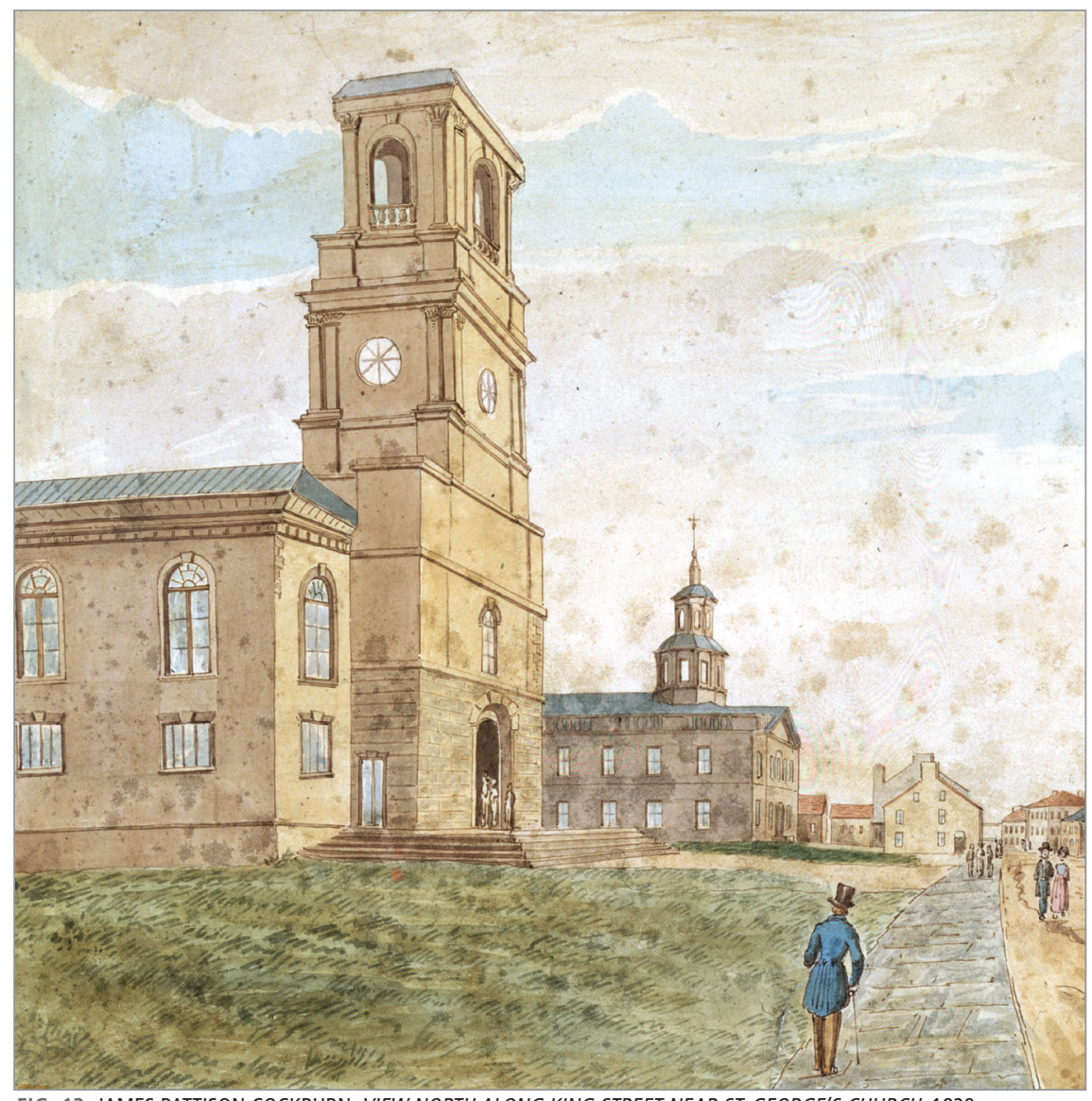

FIG. 13. JAMES PATTISON COCKBURN, VIEW NORTH ALONG KING STREET NEAR ST. GEORGE'S CHURCH, 1829, WATERCOLOUR AND INK ON PAPER. AGNES ETHERINGTON ART CENTRE, QUEEN'S UNIVERSITY, KINGSTON. GIFT OF CHANCELLOR AGNES BENIDICKSON, 1987 (30-091). | LARRY OSTROM.

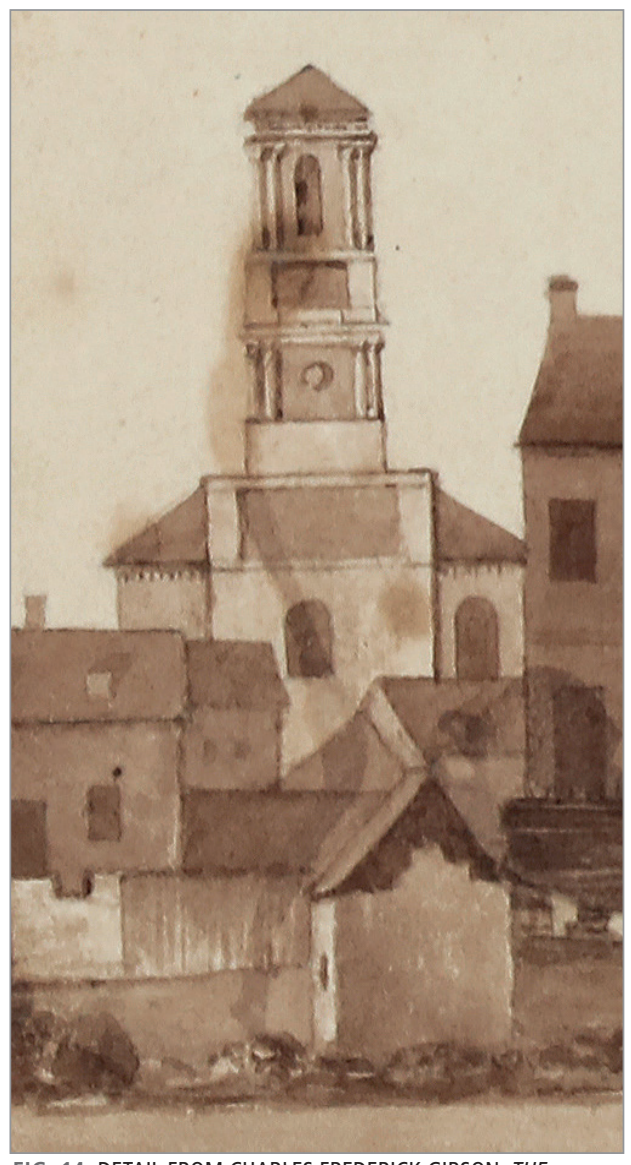

FIG. 14. DETAIL FROM CHARLES FREDERICK GIBSON, THE WATERFRONT AT KINGSTON FROM THE ST. LAWRENCE RIVER, AROUND 1832, PENCIL, SEPIA AND GREY WASH ON PAPER. AGNES ETHERINGTON ART CENTRE, QUEEN'S UNIVERSITY, KINGSTON. PURCHASE, CHANCELLOR RICHARDSON MEMORIAL FUND, DONALD MURRAY SHEPHERD BEQUEST FUND, SUSAN M. BAZELY, JOHN GRENVILLE, BRIAN S. OSBORNE AND JOAN M. SCHWARTZ, 2016 (59-014.01). | BERNARD CLARK.

The sixth stage as shown by Cockburn (and more clumsily by the ROM drawing) repeated the features of the fourth stage in a somewhat shorter and narrower format. The seventh stage of the tower, the belfry, was the tallest one in the upper part of the tower. It featured double pilasters with Corinthian capitals at each corner, long arched openings on each side, with surrounds like those on the windows below, and balusters on the lower part of the openings, as if inviting the observer to climb the tower and safely look out over the town. ${ }^{76}$ At the top stood a cap 


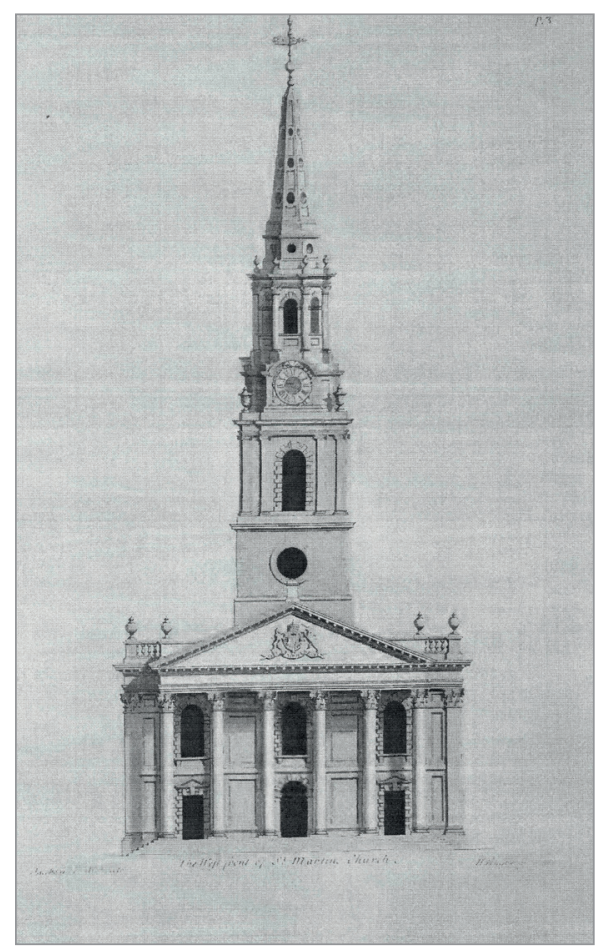

FIG. 15. ST. MARTIN'S IN THE FIELDS, WEST FAÇADE AND TOWER. | GIBBS, A BOOK OF ARCHTECTURE, 1728, PLATE 3.

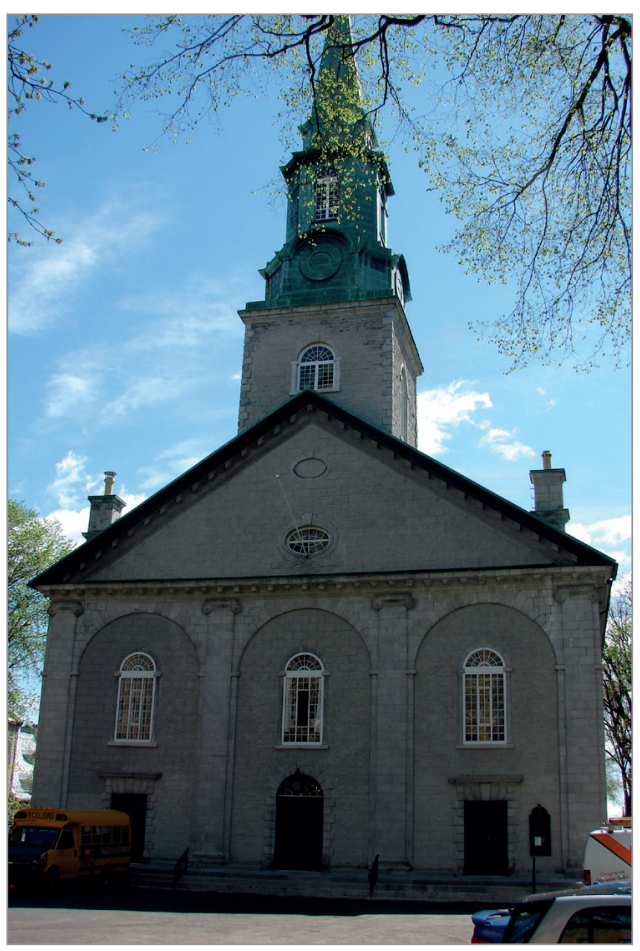

FIG. 16. WEST FAÇADE AND TOWER OF HOLY TRINITY ANGLICAN CATHEDRAL, QUEBEC. | PAUL CHRISTIANSON, 2011.

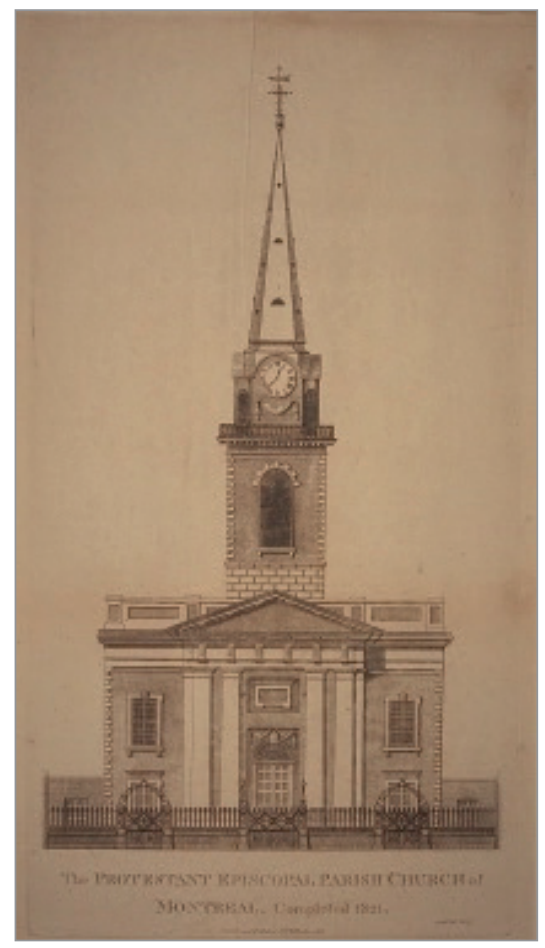

FIG. 17. THE PROTESTANT EPISCOPAL CHURCH OF MONTREAL. COMPLETED 1821 [I.E. CHRIST CHURCH ANGLICAN]. PRINT. | MCCORD MUSEUM, MONTREAL, M1242. to the tower in the shape of a pyramid. ${ }^{77}$ The tower built upon the restrained classical design of other parts of the second St. George's to appear, as Bishop Stewart called it, "so ornamental to the town."78 On the whole, the upper stages of the tower of the second St. George's gave the building a classical profile that drew upon towers by Sir Christopher Wren and James Gibbs, without feeling a need for the steeple that Gibbs added to St. Martins in the Fields. The towers illustrated by Gibbs inspired the tower of St. George's, while the steeple of St. Martins in the Fields inspired the steeples of Holy Trinity Cathedral and Christ Church. However, without its Ionic portico, the entrance façade of the second St. George's lacked the balanced compositions of the tetrastyle grand Ionic pilasters and triple arched bays of Holy Trinity (fig. 16) and the central "Doric pediment . . s supported by pairs of pilasters that formed an engaged centrepiece framing the [ritual west] façade" of Christ Church (fig. 17)..$^{79}$

The interior of the second St. George's presents even more challenges than the exterior, with the earliest surviving evidence coming from the description of the interior in a newspaper article entitled "Memoranda Taken During a Tour Through the Line of the RIDEAU CANAL, from Kingston to Bytown, in February":

To the traveler who passes this route there is but little in the Town of Kingston to attract his attention ... In this little town there are several neat houses built of Stone, for which the shores of the Bay afford excellent quarries. The stone is of a grayish limestone quality . . . Among the buildings of notoriety is a neat English Church of this description of stone. It is well finished as far as it has gone. The pews are painted white in the panels with interstices of a light gray. The Pulpit, Reading-desk, and copings of the pews of black walnut. The Galleries and ceiling are supported by handsome plain pillars of the Ionic order surmounted with a neat cornice of fancy work, from which spring deep groins which divide the roof part of the ceiling into compartments. Owing to some serious defect in its construction, the steeple which is carried to its intended height has given way; and is now so rent and twisted from the perpendicular, that it has been considered unadvisable to raise the spire upon it, and it still stands in an unfinished state. A mistake less pardonable, for it cannot be an accident, is observable in the pews - they have no kneeling boards in them although well known to be an essential in a Church of this description. The Books though of the best and largest editions are very defective in appearance. Being bound 


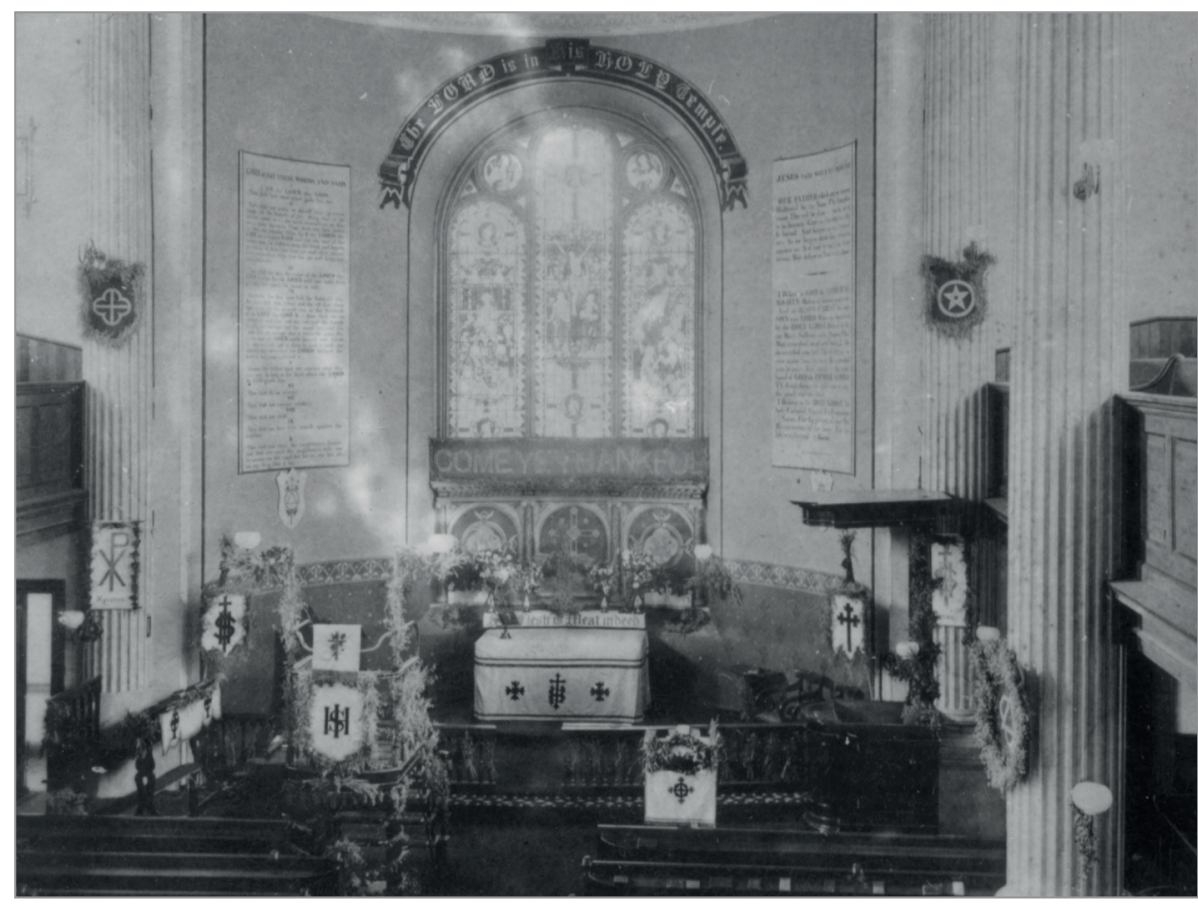

FIG. 18. PHOTOGRAPH OF INTERIOR OF ST. GEORGE'S CATHEDRAL, C. 1874 TO 1891. | SWAINSON (ED.), ST. GEORGE'S CATHEDRAL, P. 32, FIG. 1.

with rough calf or light coloured sheep-skin, [they] have more the appearance of a set of Merchant's books than such as befit the solemnity of a Church. ${ }^{80}$

This description includes a good deal of information on the interior and furnishings of the second St. George's and helps to explain the later photographs. The only visual sources are two photographs, the earlier toward the entrance (see fig. 20) and the later toward the chancel (fig. 18). Both date from after the changes of 1839-1847, the earlier from before and the later from after the pew changes of 1874. Major changes in worship had taken place before the second photograph was taken, but it does show aspects of the original interior, including the tall Ionic columns, the internal apse that served as a chancel, and a large window opening with a round arch. However, many of the furnishings in this space came from well after the 1820s. The "tablets" of the Ten Commandments on the left and the Lord's Prayer and Apostles' Creed on the right were installed in 1844, the Communion Table of 1825-1828 was replaced by an Altar (probably in the mid-1860s or 1870s), the cathedra or bishop's throne on the right came from after 1862, the awkward metal pulpit on the left side replaced an earlier walnut one after 1862, and the stained-glass window in the chancel was donated in 1881.81 Rogers designed a "black walnut" "Pulpit" and "Readingdesk" for the second St. George's, probably in a classical style as he did for St. James, Toronto, in 1831 (fig. 19). In the earlier photograph of the interior, a lectern stood on the left side of the aisle close to the front pew with a large Bible or Book of Common Prayer on the slanting top surface. ${ }^{82}$ This part of the photograph lacks the clarity design to judge

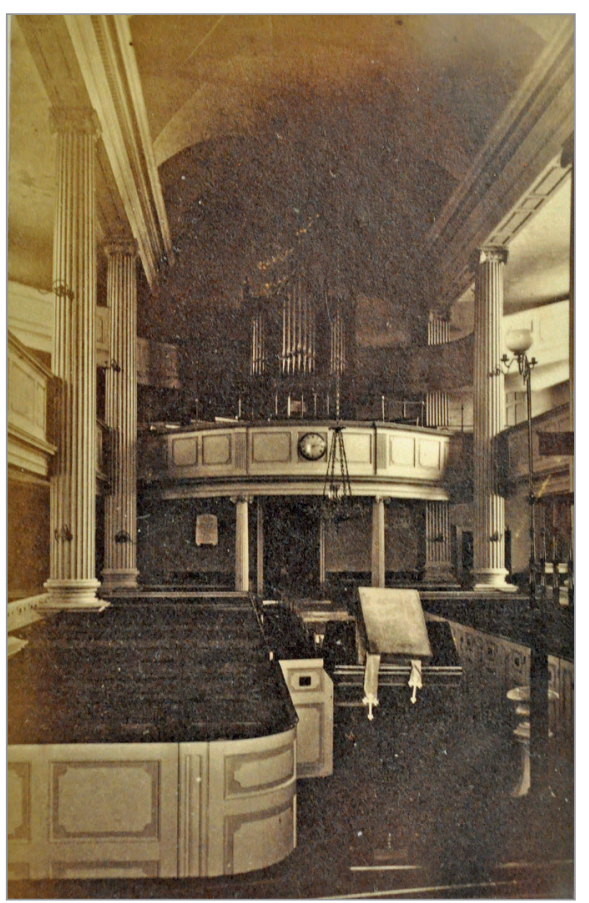

FIG. 20. PHOTOGRAPH OF THE INTERIOR OF ST. GEORGE'S ANGLICAN CATHEDRAL, KINGSTON, C. 1866. | QUEEN'S UNIVERSITY ARCHIVES 024, COURTESY OF JENNIFER MCKENDRY.

if the shaft supporting the lectern had classical lines. At St. George's until 1849, the parish clerk used a reading desk to recite aloud the responses of the people during the liturgy. In that year, the vestry voted that "for the better carrying out the Responding by the Congregation during Public Worship, the services of the Clerk of the Church in reading the responses be dispensed with." ${ }^{83}$

The photograph from c. 1866 reveals much more about the interior of the second St. George's (fig. 20). ${ }^{84}$ It provided a clearer view of the full length of the fluted Ionic columns, with their capitals, and the fluted pilasters. During the changes of 1839-1843, however, the entablature had been lengthened, the inner wall of the old tower taken down, and the pilasters with their bases moved to the new ritual west wall of the nave. The giant wooden columns stood on high 


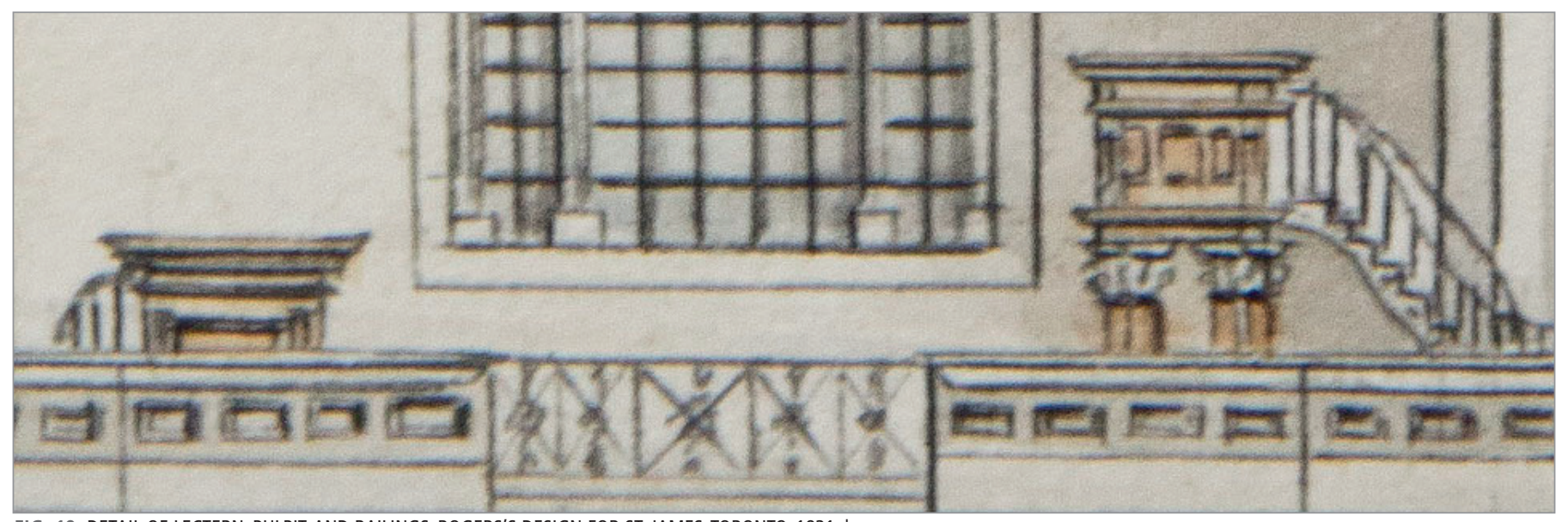

FIG. 19. DETAIL OF LECTERN, PULPIT, AND RAILINGS. ROGERS'S DESIGN FOR ST. JAMES, TORONTO, 1831. | ARCHIVES OF THE CATHEDRAL CHURCH OF ST. JAMES, TORONTO, DETAlL OF PHOTOGRAPH 20200122_166.

rectangular pedestals that raised their round bases to the height of the pews, as did those at Holy Trinity, Quebec. They supported the front of the side galleries at a level less than half of the height of the columns and continued up to the large Ionic capitals, "surmounted with a neat cornice of fancy work," by which the traveller who described the interior of St. George's in 1830 meant an entablature consisting of an architrave, frieze, and cornice. ${ }^{85}$ Rogers probably derived this dramatic treatment of space from the design of Christ Church, Montreal. However, he improved that design in several ways. The traveller also noted that from the entablature above the columns at St. George's "spring deep groins which divide the roof part of the ceiling into compartments." ${ }^{86}$ These arched indentures added life to the rounded ceiling without disturbing the horizontal lines of the entablatures. Crucially, Rogers kept the full height of the ceiling throughout the whole of the nave and into the interior chancel apse, as seen in figures 18 and 20 (minus the further range of galleries swirling around the organ in the latter that were added at a later date). This preserved the lofty presence of the central space.
A comparison to the columns and ceilings of Holy Trinity Cathedral, Quebec, and Christ Church, Montreal, confirms both the similarities and the differences. St. George's had an interior based, in part, on that of Christ Church, with tall, fluted Ionian (instead of Corinthian) columns, supporting the side galleries less than half-way up and an extended entablature above the capitals. A contemporary wrote of Christ Church: "The side galleries are supported by the main columns, and the Organ gallery in the end in which the Choir sits, is supported by columns of the Corinthian order, very well executed." ${ }^{87}$ At Christ Church, however, the columns stood on the floor, which exposed the footings only on the aisles. The barrel vault over the central space at Christ Church extended only to the opening for the chancel, an interior apse that intruded into the nave with the aisles and galleries continuing beyond (fig. 21). The "recess for the Altar" had "an Eliptical [sic] form with a semi domical ceiling or head supported upon columns of the Corinthian order with the whole entablature beautifully enriched. The face of the semidome is ornamented with an architrave and soffit enriched." 88
Instead of a continuous high central space, however, the short and narrow apse combined with a quite slim central aisle made the nave of Christ Church feel truncated in relation to the long lofty feel of St. George's. In Quebec, smooth, more slender columns supported the ceiling with arches rather than long entablatures, creating many more curved surfaces. The interior apse at Holy Trinity displayed three semicircular arches over the middle window and the panels on the sides displaying the Lord's Prayer, Apostles' Creed, and Ten Commandments. However, the central aisle and height of the interior apse reaching gracefully up to the tall ceiling at Holy Trinity helped to preserve the perception of its space (fig. 22). Still, it lacked the majesty of the tall fluted Ionic columns supporting long entablatures that marked the second St. George's. The difference made the latter look like a lofty basilica with galleries. Even the stone St. James in Toronto, although longer and wider than the second St. George's and having interior pillars that ran from the floor to a cornice around the ceiling, probably lacked the soaring interior height and perceived length of the St. George's interior. 


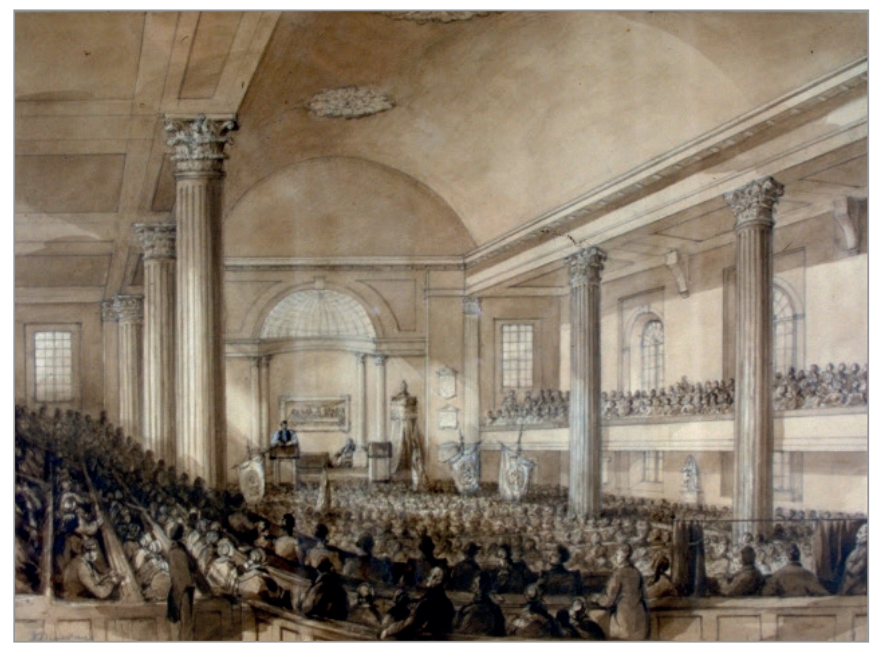

FIG. 21. JAMES DUNCAN, INTERIOR VIEW OF CHRIST CHURCH CATHEDRAL, MONTREAL PAINTING. | MCCORD MUSEUM, MONTREAL, M6015.

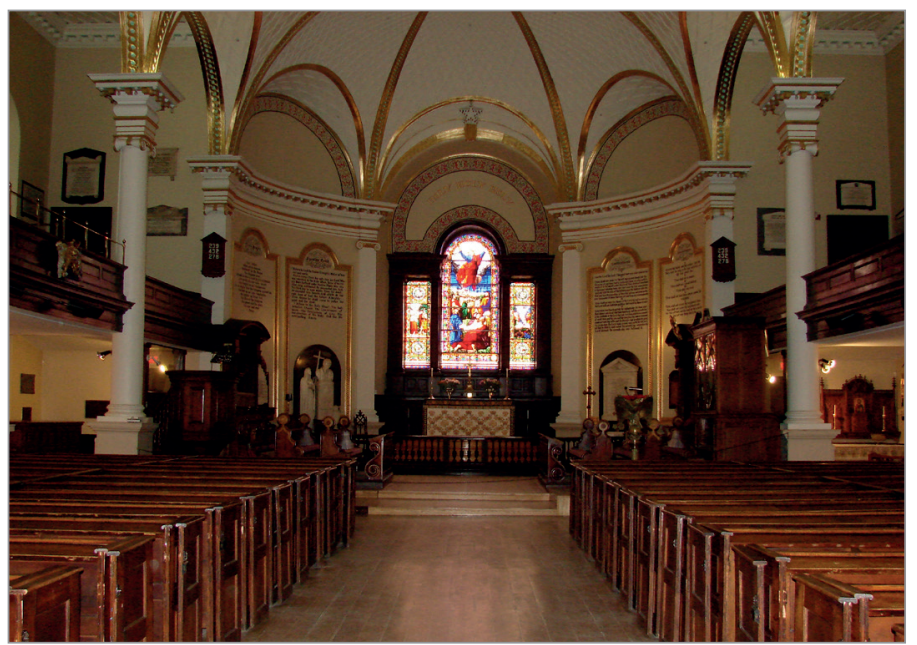

FIG. 22. INTERIOR OF HOLY TRINITY ANGLICAN CATHEDRAL, QUEBEC, TOWARD THE CHANCEL. | PAUL CHRISTIANSON, 2011.
The early photograph of the interior of St. George's also reveals the layout and nature of the box pews on both sides of the central aisle on the ground floor (see fig. 20). These pews had doors at each end and were owned or rented by people who attended services. The rents provided an important source of revenue. Most of the pews dated from 1825-1828, including those between the side aisles and the wall that may be glimpsed behind the closer pillar on the left side of the photograph. However, four pews at the chancel end-two large ones on each side of the central aisle and one at the head of each side aisle-had been added in the same style during a major building of new pews in 1841-1843. In the Vestry Meeting of April 18, 1842, the attending churchwarden, John Macaulay, made an important report:

Mr. Macaulay stated to the Vestry, that in concurrence with the Rector and Assistant Minister, the Churchwardens in order to meet as far as possible under present circumstances, the urgent demand for sittings, had made arrangements for erecting four new pews on the ground floor, in the vacant spaces, near the chancel, and ranges of pews in the galleries in lieu of the present open seats against the wall, which was approved of. 89

Large galleries were built along both sides (in 1825-1827); they contained pews at the chancel end and along the front, with open seats at the back. A visitor to St. George's in early 1830 reported that the "pews are painted white in the panels with interstices of a light gray," with the "copings of the pews of black walnut." 90 He also displayed shock that they did not contain "kneeling boards," which revealed both his own High Church assumptions and the conservative worship styles of St. George's, with its leather bound "Books"-the Book of Common Prayer and the Bible-of "the best and largest editions" for the clergy and clerk who led the service. When the Building Committee called for tenders "for the Painting and Coloring of St. George's CHURCH" in 1842, they specified: "The new work to be painted three times and the old work twice. The walls to be colored light buff and the ceilings white. The walnut work to be varnished." ${ }^{91}$ In the photograph of the interior, the colour scheme of the pews from 1827 appeared to have remained the same. The large painted panels at the front of the pews probably came from 1827 and were moved forward to the new pews built there in $1842 .{ }^{92}$ The painted pews with varnished walnut copings were closer to those at Christ Church, Montreal, with their white painted sides and varnished cherry trim, than to the oak pews at Holy Trinity Cathedral.

The large, curved gallery across the ritual west end, shown in the photograph as supported by two smaller lonic columns, probably was built in 1825-1827, and followed the general pattern of the one supported by two smaller Corinthian columns at Christ Church. Originally, the west gallery at St. George's had to bend forward because the inner wall of the tower extended into the nave. In 1826, this gallery housed a small organ moved from the wooden St. George's and had some space for the choir. The new, larger organ shown in the photograph (see 
fig. 20) was installed in 1842 as a gift from the choir. In the early nineteenth century, it was common in British North America for Anglican churches with galleries to locate the organ and choir in a gallery at the ritual west end of the nave. Both the side and back galleries were faced by large painted panels like those on the front pews below, a small moulding at the bottom, large walnut mouldings part way up, and a rounded walnut "coping" at the top. The higher galleries seen in the photo looping to the sides of the organ were built well after 1825-1827.

On November 25, 1827, when it finally opened for worship, the second St. George's was the largest Anglican Church in Upper Canada. The Upper Canada Herald marked the occasion with a brief article.

Divine service was performed in this elegant and commodious Church, for the first time, on Sunday last. Prayers were read by the Rev. William Macauley, the Rev. Mr. Tunny, Chaplain to the forces, officiated at the Communion Table, and the Rev. Dr. Stuart, Archdeacon of Kingston and Rector of the Parish of St. George, preached an appropriate sermon from I Sam. 12 Chap. 24 ver."Only fear the Lord, and serve him in truth, with all your heart: for consider how great things he hath done for you." ${ }^{93}$

For Upper Canada, this "elegant and commodious" building marked a new type of Anglican church in size, materials, and design. It followed the classical style of many contemporary English churches and the three largest Anglian sanctuaries in British North America: St. Paul's Church, Halifax (1760; becoming a Cathedral in 1787), Holy Trinity Cathedral, Quebec (1800-1804), and Christ Church, Montreal (1805-1814). Only the last two had walls of stone. Neither Holy Trinity nor Christ Church had a tetrastyle Ionic portico, but then neither did St. George's as built. Holy Trinity had Ionic pilasters on the ritual west and east façades and Christ Church had Tuscan pilasters on the ritual west façade. Had the Kingston congregation raised another $£ 1,500$, it could have boasted of the most elegant entry façade of any Anglican church in British North America. As completed, however, observers might question its contrasting textures of stonework and horizontal confusion, but could still admire the tall, classical tower, with its different stages, including two with double pilasters. As a whole, the church as built was both a social and architectural accomplishment worthy of celebration in a formal way that gave the congregation special recognition.

During his extensive visitation of Upper Canada in 1828, Bishop Stewart delivered on his earlier promise to consecrate the second St. George's, formally setting it aside as a holy place, favoured by God. In the Anglican Diocese of Quebec, this rite had been performed by his predecessor only at Holy Trinity Cathedral in Quebec. At Kingston, Bishop Stewart preached upon a passage containing the words of Jacob consecrating a pillar of stone at Bethel, after awaking from a dream in which he saw a ladder into heaven with angels ascending and descending and with God at the top promising to support Jacob's descendants. ${ }^{94}$ Many clergy and lay people participated in this religious event. It marked the transition from a modest wooden building erected in a frontier settlement of wooden structures to a large stone church in an urban community with an increasing number of stone houses and public buildings. The children of those Loyalists and British immigrants who had established a congregation of Church of England and Ireland in Kingston, Upper Canada, would have rejoiced at the sermon and at the honour bestowed upon their community by having their church singled out as the first parish church consecrated in the whole Diocese of Quebec. Such recognition honoured their own contribution of hiring a professional architect to design and supervise the construction of a new stone church to carry on the commitment of their ancestors in an increasingly prosperous and settled community. The second St. George's stood as the most sophisticated and largest Anglican church in Upper Canada and as other structures came to challenge its supremacy, the clergy and members of the congregation would, on several occasions in the future, rise to the challenge of expanding and improving the church built in 1825 to 1827 .

\section{NOTES}

1. I would like to thank Pierre du Prey, Jennifer McKendry, and Malcolm Thurlby for reading earlier drafts of this paper and greatly helping to improve it.

2. Varty, Carmen Nielson, 1998, "Building Identities: St. George's Anglican Churches, Kingston, Upper Canada 1792-1826," Canadian Society of Church History: Historical Papers 1998 , p. $112-128$, at p. 116

3. Ibid.

4. Id., p. 118. Varty based her interpretation of this move of the pulpit upon an interior drawing of St. George's made to indicate the location and ownership of pews from about 1817 (Varty, p. 117, fig. 2). The dimensions came from a letter of Rev. John Stuart to Bishop Charles Inglis in March 1792, quoted in Swainson, Donald (ed.), 1991, St. George's Cathedral: Two Hundred Years of Community, Kingston, Quarry Press, p. 7.

5. Preston, Richard A. (ed.), 1959, Kingston before the War of 1812: A Collection of Documents, Toronto, Champlain Society, p. xc. Later historians have quoted this passage often. I would like to thank Jennifer McKendry for passing on this reference.

6. For "auditory churches," see Addleshaw, G.W.O. and Frederick Etchells, 1948, The Architectural Setting of Anglican Worship, London, Faber and Faber Limited, p. 52-63. For comparisons, see Friary, Donald Richard, 
1971, The Architecture of the Anglican Church in the Northern American Colonies: A Study of Religious, Social, and Cultural Expression, Ph.D. dissertation in history, University of Pennsylvania.

7. Rogers, Philip, 1991, "A Joyful Noise: The Musical Tradition of St. George's," in Swainson (ed.), St. George's Cathedral, op. cit., p. 67-96, 280-284, at p. 70.

8. After this church was built, panels painted green were added above the windows to make them look Gothic; I have manipulated this photo to remove them.

9. Epstein, Clarence, 2012, Montreal City of Spires: Church Architecture during the British Colonial Period 1760-1960, Montreal, Presses de l'Université du Québec, p. 43-49; and 1825, "An Account of Christ's Church in the City of Montreal, Province of Lower-Canada," The Canadian Magazine and Literary Repository, no. 24 , vol. 4, p. 525-531. Christ Church was a large, classical stone church: "120 feet in length, by about 80 in width... The side walls are about 30 feet high" (p. 530).

10. Osborne, Brian S., 2004, The Sword and the Rock: A History of St. Andrew's Presbyterian Church, Kingston, Ontario, Kingston, Heinrich Heine Press, p. 43-48.

11. Stewart, J. Douglas and Ian E. Wilson, 1973, Heritage Kingston, Kingston, Queen's University, p. 115. The ceremony of laying the cornerstone, on July 20,1820, was presided over by Thomas Markland, "Chief Magistrate," assisted by his son George Herchmer Markland and others (p. 114-115). For the addition, see Wilson, Joseph M., 1861, The Presbyterian Historical Almanac, and Annual Remembrance of the Church, vol. 3, Philadelphia, "Joseph M. Wilson," p. 264-267, at p. 264. I would like to thank again Jennifer McKendry for bringing this work to my attention.

12. Archives of the Anglican Diocese of Ontario (ADOA) (Kingston, Ontario), 2-KM-3, St. George's Kingston, Vestry Book 1817-26, under payments, March 20, 1822. Rev. John Bethune became the rector of Christ Church, Montreal, in 1818 and remained as rector there and dean after it became a cathedral, until his death in 1872. See Cooper, John Irwin, 2000, "John Bethune," Online Dictionary of Canadian Biography (ODCB), [http://www. biographi.ca/], accessed January 6, 2020.

13. This laconic note recorded the payment for a "Plan and Elevation," but did not indicate who made it. William Berczy, the architect of Christ Church, Montreal, died in 1813.
14. See Noppen, Luc and Lucie K. Morisset, 1996, La Présence Anglicaine à Québec : Holy Trinity Cathedral (1796-1996), Quebec, Septentrion; and Epstein, 2012, Montreal City of Spires, op. cit., p. 43-49.

15. ADOA, 2-KM-3, February 12, March 31, and April 1 and 10,1823 . The $f 25$ was substantial enough for an architect to draw up plans and a model for a church.

16. Spragge, Shirley C., 1983, "'The Sovereign's Munificence' and The Rectory Fund of Kingston," Journal of the Canadian Church Historical Society, vol. 25, April, p. 8; quoting Archives of Ontario (AO), RG $1 \mathrm{Cl}-1$ Crown Land Papers, Box 25, 27 Feb. 1805.

17. Id., p. 9; quoting AO, RG 1 Crown Lands C IV, Box 264.

18. Ibid.

19. Id., p. 11; citing Queen's University Archives, Land Registry Copy Book H, Frontenac County, Inst 160, 26 Aug. 1824. For the financing of the erection of the second St. George's, also see Spragge, Godfrey, 1991, "For Use and Benefit: The Land Records of St. George's," in Swainson (ed.), St. George's Cathedral, op. cit., p. 99-116, 285-287, at p. 107-108.

20. McKendry, Jennifer, 2019, Architects Working in the Kingston Region, 1820-1920, Kingston, Jennifer McKendry, p. 78. I would like to thank Jennifer McKendry for drawing the architect and date of laying the cornerstone for the Midland District Courthouse to my attention. A British traveller described it very favourably: "Among the public buildings, the Court House is the most prominent. It stands near the centre of the town, opposite to the principal hotel, and within a few yards of the English church. The Court House has a front of about 100 feet, a depth of 200 feet, and is about 60 feet in height. The front has a pediment, above and behind which rises an octagonal tower, with lantern and cupola, to a height from 50 to 70 feet above the roof, making the whole elevation, with the terminating spire, about 150 feet. The interior is spacious and well arranged; and on the upper floor is one of the best fitted Court-rooms in the province." Buckingham, James S., 1843, Nova Scotia, New Brunswick, and the Other British Provinces in North America, London, Fisher, Son, and Co., p. 62. The watercolours of Cockburn and Gibson have views that encompass both the Court House and the Second St. George's; see note 57 below.

21. ADOA, 2-KM-3, id., April 9, 1825.
22. Varty, "Building Identities: St. George's Anglican Churches," op. cit., p. 123. Thomas Markland was a prosperous merchant, militia officer, magistrate, and active member of the Kingston community, while his son George Herchmer was a successful politician and office holder. Christopher Hagerman was an aggressive lawyer, militia officer, office holder, and judge, who strongly supported Church and King. John Macaulay, the son of a successful Loyalist merchant, became prominent businessman, office holder, militia officer, politician, and justice of the peace in Kingston, and owner of the Kingston Chronicle, in which he published articles and letters upholding Church and State. John Kirby became a prominent Kingston merchant, associated in the early days with Thomas Markland's father, he married John Macaulay's aunt Mary, and raised John and his brothers after the early death of their father. A strong Anglican, he helped to finance the new St. George's in the 1820 s and was very active in aiding benevolent and medical activities. See Errington, Jane, 2000, "Thomas Markland," ODCB, accessed December 6, 2019; Burns, Robert J., 2000, "George Herchmer Markland," ODCB, accessed December 18, 2019; Fraser, Robert Lochiel, 2000, "Christopher Alexander Hagerman," ODCB, accessed December 18, 2019; Fraser, Robert Lochiel, 2000, "John Macaulay," ODCB, accessed May 1, 2006; Wise, S.F., "John Macaulay: Tory for all Seasons," in Gerald Tulchinsky (ed.), 1976, To Preserve and Defend: Essays on Kingston in the Nineteenth Century, Montreal and London, McGill-Queen's University Press, p. 185-202 and 364-366; and Errington, Jane, 2000, "John Kirby," ODCB, accessed December 18, 2019.

23. Bowsfield, Hartwell, 2000, "Sir Peregrine Maitland," ODCB, accessed December 22, 2019.

24. ADOA, St. George's, Minutes of Building Committee 1825-27, 2-KM-4, Friday, April 15, 1825.

25. Id., April 20, 1825.

26. Spragge, "The Sovereign's Munificence," op. cit., p. 9: "In October 1825, Stuart and his wardens received the patent for town lots 122, 139 142, 159 and 162 for the church and parsonage."

27. ADOA, 2-KM-4, May 11 and 12, 1825

28. Id., May 13 and May 26, 1825.

29. Id., May 30, 1825.

30. Id., May 31, 1825. 
31. Id. It would take more than a year before the committee heard that their request had been granted. The reference to Quebec and Montreal referred to the erection of Holy Trinity Cathedral, Quebec City, consecrated in 1804, and Christ Church, Montreal, designed by William Berczy, where the cornerstone was laid in 1805, the church opened in 1814, and the galleries and spire finished in 1820. See Noppen and Morisset, 1996, Holy Trinity Cathedral, op. cit.; and Epstein, 2012, Montreal City of Spires, op. cit., p. 43-49. Both obtained considerably more funding from the government than Kingston; Christ Church receiving $£ 4,000$ in 1818 , plus an organ that cost $f 1,150$. Canadian Magazine, June 1825, p. 528-529.

32. ADOA, 2-KM-4, June 1, 1825.

33. Id., June 11, 1825: "To Mr George Oliver, Master of St. John's Lodge no. 5, Kingston."

34. Id., "Memorandum" on the page after the letter of June 11, 1825.

35. See the account from the Kingston Chronicle in Stewart and Wilson, Historic Kingston, op. cit., p. 114-115, notes to fig. 139.

36. ADOA, 2-KM-4, June 23, 1825.

37. Id., "Memorandum" on page before letter of June 23, 1825 and Chronicle, June 24, 1825 , p. 3 , col. 1 . The $37^{\text {th }}$ North Hampshire Regiment served in Quebec City in 1821-1824 and in Kingston in 1824-1825, where it was commanded by Lt. Col. Gabriel Burer; see Whitting, John Everard, 1878, Annals of the Thirty-seventh North Hampshire Regiment, Winchester, Warren \& Son, p. 21 and 50.

38. Chronicle, June 24,1825 , p. 3, col 1. Thanks to Heather Home for obtaining a copy of this article when the restrictions of the Covid-19 crisis made it otherwise inaccessible to me.

39. ADOA, 2-KM-4, June 23, 1825.

40. Compare this with the ceremonies at the laying of the cornerstone of St. Mark's Anglican Church, Barriefield, with prayers offered by Archdeacon Stuart and Rev. Bartlett, and of St. James' Anglican Church, Stuartville, presided over by the Bishop of Toronto; these were reported briefly in the British Whig, July 15, 1843 , and October 4, 1844. For the building of these churches, see Christianson, Paul, 2010, "St. Mark's Anglican Church, Barriefield, and the Gothic Revival in Canada West," Journal of the Society for the Study of Architecture in Canada / Journal de la Société pour l'étude de l'architecture au Canada, vol. 35, no. 1, p. 17-30; and 2012, "The Building of
St. James' Anglican Church, Stuartville: Social and Architectural Sources," A Collection of Talks of Historical Interest 2012, Kingston, Pittsburgh Historical Society, p. 11-25, at p. 12-13. Rev. Thomas Henry Marsh Bartlett was chaplain to the Garrison in Kingston at the time. See Ruggle, Richard E., 2017, Anglican Clergy of Upper Canada / Canada West / Ontario Ordained before 1932, [_], accessed May 2019. This valuable online compilation lists the clergy alphabetically by last name.

41. ADOA, 2-KM-4, September 8 and 17, 1825.

42. Young, A. H., 1927, "The Rev'd. Young, A. H., 1927, "The Rev'd George Okill Stuart, M.A. LI.D," reprinted from Papers and Records, vol. 24, Toronto, Ontario Historical Society, p. 21-22.

43. Id., p. 22.

44. ADOA, 2-KM-4, December 24, 1825.

45. Id.

46. St. George's continued to worship in a conservative manner, with the Archdeacon or Assistant Minister reading the appropriate portions of the liturgy and the parish clerk reading the responses of the people, until ended by a motion passed in Vestry in 1849: "That for the better carrying out the Responding by the Congregation during Public Worship, the services of the Clerk of the Church in reading the responses be dispensed with." ADOA, 2-KM-6, Vestry Book 1849-1889, April 9, 1849. Music played an important part in worship, accompanied at first by bands from the forces and from 1817 until 1842 by a small organ, which was moved to the gallery at the entrance end, where seating was arranged for the choir. From 1828-1844, St. George's had a professional organist, Richard Gornall, who helped to establish a strong musical tradition there and in the community of Kingston, advertising that he would teach singing and various musical instruments to pupils as early as 1829 . Rogers, "A Joyful Noise," op. cit., p. 70-73.

47. ADOA, 2-KM-4, July 15, 1826.

48. Id., August 1, 1826.

49. Chronicle \& Gazette, September 22,1826, p. 2 , col. 3. Delivered on September 18, 1826.

50. Id., p. 2, col. 3-4. Delivered on September 18 , 1826.

51. Id., p. 2, col. 4. Delivered on September 18, 1826.

52. ADOA. 2-KM-4, August 5, September 17, October 6, and November 11, 1826.
53. Id., October 6 and October 10, 1826.

54. Id., February 21, 1826. These projects appear to have been finished, with payments made on April 3 and July 23, 1826.

55. ADOA, 2-KM-3, March 10, 1826: "Cash paid H.C. Thomson Advertising Sale of Church 4s/7d"; March 15, 1826: "Cash paid Jas. Macfarlaine do. do. 4s/7d"; March 27, 1826: "Cash paid to S.O. Tazewells for removing the organ $f 2 / 7 / 2$ ".

56. Queen's University Archives (QUA), KAD-6.

57. James Pattison Cockburn, View North Along King Street Near St. George's Church, 1829, watercolour and ink on paper. Agnes Etherington Art Centre, Queen's University, Kingston. Gift of Chancellor Agnes Benidickson, 1987 (30-091), photo credit: Larry Ostrom and Charles Frederick Gibson, The Waterfront at Kingston from the St. Lawrence River, around 1832, pencil, sepia and grey wash on paper. Agnes Etherington Art Centre, Queen's University, Kingston. Purchase, Chancellor Richardson Memorial Fund, Donald Murray Shepherd Bequest Fund, Susan M. Bazely, John Grenville, Brian S. Osborne and Joan M. Schwartz, 2016 (59014.01); photo credit: Bernard Clark. For a very distant views of the tower, also see Frome, Edward Charles, Kingston, Taken from the Top of a House, 1833, 17-039, Agnes Etherington Art Gallery, and Cockburn, James Pattison, View down Brock Street from the Western Outskirts of Kingston, 1829, National Archives of Canada, C-12638, pen and ink and watercolour over pencil, in Stewart and Wilson, Historic Kingston, op. cit., p. 95, fig. 98.

58. Royal Ontario Museum; published in Alodi, Mary, 1974, Canadian Watercolours and Drawings in the Royal Ontario Museum, 2 vols., Toronto, Royal Ontario Museum, vol. 2, item 2271, St. George's Church, Kingston, brown wash over pencil, c. 1833.

59. I would like to thank Jennifer McKendry for bringing to my attention the fact that maps of Kingston from 1850, 1865, 1869, and 1877 do not show St. George's with an external apse.

60. McKendry, Jennifer, 1988, "The Architects of St. George's Cathedral, Kingston," Queen's Quarterly, vol. 95, no. 3, p. 702. Sir Christopher Wren in St. Andrew, Holborn, and St. James, Piccadilly, Nicholas Hawksmoor in St. Alphege's, Greenwich, and the east façade of St. Anne's, Limehouse, and James Gibbs in St. Martin's in the Fields popularized the use of smaller windows below and taller arched windows above. See [www. 
london-city-churches.org.uk/Churches/ StAndrewHolborn/index.html]; and [www. pinterest.ca/pin/467248530065387139], sites accessed January 2020; du Prey, Pierre de la Ruffinière, 2000, Hawksmoor's London Churches: Architecture and Theology, Chicago and London, University of Chicago Press, p. 76, fig. 37 and coloured plate 5; and Gibbs, James, 1728, A Book of Architecture, Containing Designs of Buildings and Ornaments, London, no publisher, plate 7. It was used in the early nineteenth century in classical churches with galleries, including Holy Trinity Cathedral, Quebec, which has smaller windows with slightly rounded arches below and taller windows with round arches above. See Noppen and Morisset, 1996, Holy Trinity Cathedral, op. cit., p. 117, with its illustrations of St. Martin's, Holy Trinity, and Marylebone Chapel (1818). For contemporary examples designed by Robert Smirke in England, see Port, M.H., 2006 [ $2^{\text {nd }}$ ed.], 600 New Churches: The Church Building Commission, 1818-1856, Reading, Spire Books Ltd., p. 60 fig. 22, and p. $71-72$ figs. 31,32 , and 33 .

61. The window openings of the early walls measure 5.5 feet wide and the spacing of the walls between 11.5 feet, with an estimated 6.75 feet of wall beyond the first and fifth bays.

62. McKendry, Jennifer, 1995, With Our Past before Us: Nineteenth-century Architecture in the Kinston Area, Toronto, University of Toronto Press, p. 61, fig. 31. This work was traditionally attributed to Harriet Dobbs Cartwright, but has received a more recent attribution to the office of George Brown. See Stewart, J. Douglas, 1991, "George Brown's Influence: The Architectural Heritage of St. George's," in Swainson (ed.), St. George's Cathedral, op. cit., p. 29-63 and 278-280, at p. 56 and 60.

63. This photograph of the interior of St. George's was taken after the replacement of the original box pews by slip pews in 1874 and before the additions of 1891.

64. I would like to thank Nancy Mallett, archivist and museum curator at the Cathedral Church of St. James, 65 Church Street, Toronto, ON, $\mathrm{M} 5 \mathrm{C} 2 \mathrm{E9}$, for generously providing digital versions of the designs for the stone St. James of 1831 and of the manuscript contracts for building that church. In his notebook on the interior changes made in 1842-1843, Coverdale mentioned removing the vestry doors, which could have referred to the doors on these rooms. See McKendry, Jennifer, 1991, "William Coverdale and the Architecture of Kingston from 1835 to 1865 ," 2 vols., Ph.D. dissertation in art history, University of Toronto, vol. 1, p. 165 , footnote 11

65. Stewart, 1991, "George Brown's Influence," op. cit., p. 29-63 and 278-280, at p. 30.

66. The columns would have stood 27 feet high by 2.5 tapering to 2 feet wide, with an entablature 31 feet wide by 2 feet high and a pediment 35 feet wide by 10 feet high.

67. In Rogers's design, the stylobate was portrayed as 5 feet high by 50 feet wide at the base and 40 feet wide at the top. The first three stages of the tower were 30 feet wide by around 18 feet deep, extending about 8 feet into the nave, and the flanking bays were 12.5 feet wide.

68. Knaresborough Cottage is 203 King Street East, Kingston. The monolithic blocks are on the original entrance surround on the side of the house and they also are used on the second storey window surrounds at $221 \mathrm{King}$ Street East, Kingston, built for John Solomon Cartwright in 1834 and attributed to Rogers. See Stewart, J. Douglas, and Mary Stewart, 2000, "Cartwright, John Solomon," ODCB accessed February 2007.

69. The first two stages of the tower stood 35 feet high by 30 feet wide above the stylobate.

70. In his floor plan for St. James in 1831, Rogers put the tower on very thick walls. The stairs had their own external entrances. The tower was 28 feet 6 inches square and the exterior walls that encased the staircases continued on each side for 25 feet 3 inches. A similar design would be devised for St. George's in 1839-1845, when the original tower was taken down, the nave walls extended by a bay, and a new tower and circular stairs to the galleries were added. I hope to discuss these changes in detail in a later article.

71. Military engineers drew attention to the instability of the tower in the local newspaper in 1830, with a reply by "An Architect." Chronicle, June 12, 1830, p. 3 col. 2. At a Vestry Meeting five years later: "Mr. J.S. Cartwright and Mr. Hill were requested to procure some scientific Engineer to examine the Church Tower, and to report if there is any danger of its falling, or if sufficient to support a Bell of seven or eight hundred weight." ADOA, 2-KM5 , April 20, 1835. The list of expenses in the Vestry Minutes in 1838 included the following reference: "Wm. Rice's bill, repairing stairway f0.2.6"; ADOA, id., January 15, 1838. The lists of expenses showed the Sexton doing various carpentry, but not masonry repair jobs, so the stairs to the galleries were probably made of wood. Allowing for walls 2 to 3 feet thick, the interior of the first two stages of the tower would have been 24 to 26 feet wide by 12 to 14 feet deep, just enough space to handle the traffic of people entering and exiting for worship from the main floor and taking stairs to the galleries. In his later design for Toronto, Rogers added much more room for a tower with thicker walls and for stairs to the galleries.

72. The second stage was 12 feet high and the third 5 feet high.

73. The fourth stage was 7 feet high and 18 feet square and the fifth stage was 12 feet high and 18 feet square.

74. The Building Committee agreed to have double pilasters on the tower, as suggested by the architect: "It was resolved that their offer be taken and that Double Pilasters be made instead of the single there; making the whole sum now to be paid two hundred and fifteen pounds." ADOA, 2-KM-5, July 15, 1826.

75. For Wren, see St. Magnus the Martyr and St. Mary le Bow at: [www.london-city-churches. org.uk/Churches/StMagnustheMartyr/index. html]; and [www.flickr.com/photos/friendsofthecitychurches/15703487624], sites accessed January 2020. For Hawksmoor, see du Prey, 2000, Hawksmoor's London Churches, op. cit., coloured plates 3 and 5; p. 86, fig. 42; and p. 95, fig. 49. The belfry stage of the steeple of St. Martin's in the Fields, London, has double pilasters on the corners of a square tower with arched openings with rusticated surrounds and two stages of the tower of a round church have double pilasters. See Gibbs, 1728, A Book of Architecture, op. cit., plate 3 "The West Front and Steeple," and plate 14 "The West Front and Steeple." I would like to thank Pierre du Prey for suggesting that I look at the London churches of Wren and Hawksmoor for earlier examples and Malcolm Thurlby for suggesting the Wren churches noted above.

76. Cockburn clearly portrayed the openings with balusters and Gibson the double pilasters. The drawing by Gibson elongated the seventh stage in relation to the other contemporary representations, including Cockburn, View down Brock Street, that showed St. George's from a much greater distance.

77. ADOA, 2-KM-5, February 21, 1827. The Building Committee reported: "Messrs. Robert Matthews and Andrew Lander having tendered to build the turrets on the Tower and the platform and steps in front of the Church, the Committee agree with them to perform 
the said work, the former for the sum of two hundred pounds to be finished by the twentieth day of June next and the latter for the sum of two hundred and thirty pounds, to be finished by the fifteenth day of July next and direct their Superintendant [sic] make out the specifications, and that Contract be thereupon drawn out." They completed this contract by April 3, 1827, and were paid for their work. This finished the outside work. Gibson drew the most coherent image of the cap.

78. See passage cited to note 51 above.

79. Epstein, 2012, Montreal City of Spires, op. cit., p. 49.

80. Chronicle, May 1, 1830, p. 2 col. 6; and p. 3 col. 1.

81. The clear windows of 1825 caused some problems during services held in the afternoon and at the Vestry Meeting of March 27, 1837: "It was ordered that the Church Wardens take steps to have the Communion Window darkened, the Pulpit Oiled \& cleaned \& the outside of all windows painted." For the "tablets," see ADDO, 2-KM-5, April 8, 1844, motion 9.

82. On November 6, 1821, a "Silver Basin, for Baptisms" was purchased for $£ 3 / 14 / 0$. AAD0, 2-KM-3.

83. ADOA, 2-KM-6, Vestry Book, April 9, 1849.

84. QUA, photo album, Interior of St. George's Cathedral, Kingston, c. 1866, 024. The gas lighting visible in various locations in the photo was installed in 1851 and the new slip pews without doors were installed in 1876. See ADOA, Vestry Book, 1849-1889, 2-KM-6, April 21, 1851; and May 29, 1876. A companion photograph of the exterior of the ritual south and east façades shows a tower from the Congregational Church on Wellington Street at the back, but not of the stone St. George's Hall, which allows it to be dated to c. 1866 . I would like to thank Jennifer McKendry for bringing these photographs to my attention.

85. Chronicle, May 1, 1830, p. 3 col. 1. The photograph does not have enough clarity to distinguish the details of the entablature, but it gives a good impression of the long high ongoing space that it helped to define.

86. Id. Several of Wren's London churches placed the interior columns on very high bases (including St. Lawrence, Jewery, St. Magnus the Martyr, and St. Martin, Ludgate); see [www.london-city-churches.org.uk/ Churches/StLawrenceJewry/index.htmll; [www.london-city-churches.org.uk/Churches/ StMagnustheMartyr/index.html]; and [www. london-city-churches.org.uk/Churches/
StMartinwithinLudgate/index.html], sites accessed January 2020. For bases the height of the pews, see St. Martin's in the Fields, London, and Holy Trinity Cathedral, Quebec City. In both of these, arches between the columns supported the ceilings. For St. Martin's, see Gibbs, 1728, Book of Architecture, op. cit., plates 11 and 12. For Holy Trinity Cathedral, see fig. 20 above.

87. 1825, Canadian Magazine, p. 525-531, at p. 530. This article also says that the interior "is 120 feet in length, by about 80 in width exclusive of the recess for the Altar which is 12 feet in depth by 40 in width. The windows are 14 feet in height topped with a semi-circular arch . . . and 7 feet wide. The side walls are about 30 feet high."

88. Id. "The Pulpit is neat and of a fanciful design, with a circular front; it is supported by six columns of the Corinthian order ... The whole along with the Reading Desk and Clerk's Seat of mahogany."

89. ADOA, 2-KM-5, April 18, 1842.

90. Chronicle, May 1, 1830, p. 3 col. 1.

91. Chronicle and Gazette, July 20, 1842, p. 3, col. 1.

92. The reorganization began in 1841, pressure for worship space started to build up when Kingston became the Capital. See ADOA, 2-KM-5, April 12, 1841.

93. Upper Canada Herald, November 27, 1827, p. 129, col. 3. For the sermon preached by the incumbent on this occasion, see Stewart, George Okill, 1827, A Sermon Preached at Kingston, Upper Canada, on Sunday, the $25^{\text {th }}$ Day of November, 1827, on Occasion of Divine Service at Opening of St. George's Church, Kingston, Hugh C. Thomson. For William Macaulay, the brother of John Macaulay, who served for many years in Picton, building the brick Anglican church there, see Millman, T.R., 2000, "Macaulay, William," ODCB, vol. 10, accessed December 6, 2019. For Reverend Robert William Tunney who served as a chaplain on the continent during the wars against France, before becoming a chaplain to the forces in Niagara 1822-1824 and in Kingston 1824-1832, see Ruggle, Anglican Clergy of Upper Canada (op. cit.), under Tunney; and Burley, Roy David, 2013, An Age of Negligence? British Army Chaplaincy, 17961844, M.Phil. thesis, University of Birmingham, School of Historical Studies, p. 167.

94. For a brief account of the consecration, see Upper Canada Herald, July 9, 1828, p. 195, col. 3. 